\title{
WYNIKI BADAŃ NA OSADZIE KULTURY PUCHARÓW LEJKOWATYCH NA STANOWISKU NR 4 W MIERZYNIE, GM. DOBRA SZCZECIŃSKA I ICH ZNACZENIE DLA WIEDZY O ŚRODKOWYM NEOLICIE DOLNEGO NADODRZA
}

\author{
THE RESULTS OF INVESTIGATIONS AT THE FUNNEL \\ BEAKER CULTURE SETTLEMENT SITE IN MIERZYN, \\ DOBRA SZCZECIŃSKA COMMUNE, SITE 4, AND THEIR \\ SIGNIFICANCE FOR THE KNOWLEDGE OF THE MIDDLE \\ NEOLITHIC IN THE LOWER ODER REGION
}

\author{
Marcin Dziewanowski \\ Instytut Archeologii, Wydział Historyczny, Uniwersytet im. Adama Mickiewicza \\ ul. Umultowska 89D, 61-614 Poznań, Poland \\ obsydianowy@poczta.onet.pl \\ Katarzyna Pyżewicz \\ Instytut Archeologii, Wydział Historyczny, Uniwersytet im. Adama Mickiewicza \\ ul. Umultowska 89D, 61-614 Poznań, Poland \\ pyzewicz@amu.edu.pl
}

\begin{abstract}
This paper presents the results of analyses of materials recovered during 2004 rescue excavations of a Funnel Beaker Culture (TRB) dwelling pit at Mierzyn, site 4. It provides a detailed and multifaceted analysis of the archaeological record and attempts to assess the significance of the find for the studies on the Middle Neolithic in the Lower Oder region. The article contains a detailed description of selected archival finds from the area occupied by the site and discusses their previous interpretations.
\end{abstract}

KEY WORDS: Wał Stobniański, Mierzyn settlement cluster, Funnel Beaker Culture, Pasewalk beakers with pointed base 
W trakcie badań nad zagadnieniem klasyfikacji kulturowo-przestrzennej znalezisk neolitycznych z młodszej epoki kamienia Kazimierz Siuchniński wyznaczył „mierzyńsko-krzekowskie” skupisko osadnicze na podstawie odkryć badaczy niemieckich oraz wyników własnych prac weryfikacyjnych. Publikacje z lat 1958-1983 (Siuchniński 1958, 1969, 1972, 1983) podsumowujące stan wiedzy i ukazujące perspektywy badań nad osadnictwem z młodszej epoki kamienia Dolnego Nadodrza ugruntowały przekonanie o doniosłej roli skupiska osadniczego z obszaru Wału Stobniańskiego i Równiny Gumienieckiej dla refleksji nad rozwojem kultur Pomorza Zachodniego. Od czasu realizacji badań AZP w 1983 r. (Sajkowska 1984) do początku XXI w. archeolodzy bazowali na kolekcjach i zapiskach archiwalnych, które wymagały podjęcia weryfikacyjnych prac terenowych.

W ostatniej dekadzie nastąpiło przyśpieszenie procesu zabudowywania przedmieść i najbliższej okolicy Szczecina. Proces intensywnego powiększania aglomeracji miejskiej następuje przede wszystkim w zachodniej części Szczecina. Obserwowane od połowy 9 dekady XX w. liczne przypadki naruszania obiektów z młodszej epoki kamienia $\mathrm{w}$ obrębie znanych stanowisk oraz poza nimi $\mathrm{w}$ trakcie zbrojenia terenu skłaniały do podejmowania prób określenia znaczenia mierzyńskiego skupiska osadniczego w rozwoju kultury neolitycznej i odpowiedzenia na pytanie o wartość traconych reliktów dziedzictwa kulturowego. Przez szereg lat podejmowano próby pozyskania danych o historii społeczności zamieszkujących wskazaną strefę w okresie epoki kamienia (Dziewanowski 2005, 2008, 2013, 2014; Dziewanowski, Matuszewska 2011). Dotychczasowy stan badań pozwala ukazać tzw. mierzyńskie skupisko osadnicze jako wartościową poznawczo sieć osad kultury ceramiki wstęgowej rytej, kultur późnego cyklu kultur wstęgowych, kultury pucharów lejkowatych i kultury amfor kulistych. Dla badaczy społeczności postmezolitycznych szczególną wartość posiadają zespoły zawierające elementy kultury rösseńskiej oraz różne warianty późnego cyklu kultur wstęgowych z elementami kultury materialnej społeczności protoneolitycznych. W świetle studiów koncepcyjnych i źródłoznawczych obszar Wału Stobniańskiego mógł odegrać znaczną rolę w transformacji systemów kulturowych obu społeczności. Przedstawiciele tych kultur korzystali między innymi z lokalnych złóż surowców naturalnych: surowców plastycznych, krzemionkowych oraz kamiennych. Istnienie wielu wychodni surowców krzemionkowych pozwalało rozwinąc miejscową produkcję krzemieniarską, czego świadectwem są liczne środkowoneolityczne pracownie krzemieniarskie.

Efektem dotychczasowych starań zmierzających ku zabezpieczeniu świadectw dorobku kulturowego społeczności neolitycznych było przeprowadzenie w $2004 \mathrm{r}$. interwencyjnych prac sondażowych na stanowisku $\mathrm{nr} 4 \mathrm{w}$ Mierzynie pod kierunkiem Tadeusza Galińskiego. W pracach uczestniczyli studenci Instytutu Prahistorii Uniwersytetu im. Adama Mickiewicza w Poznaniu, których działalność była współfinansowana przez macierzystą uczelnię. 


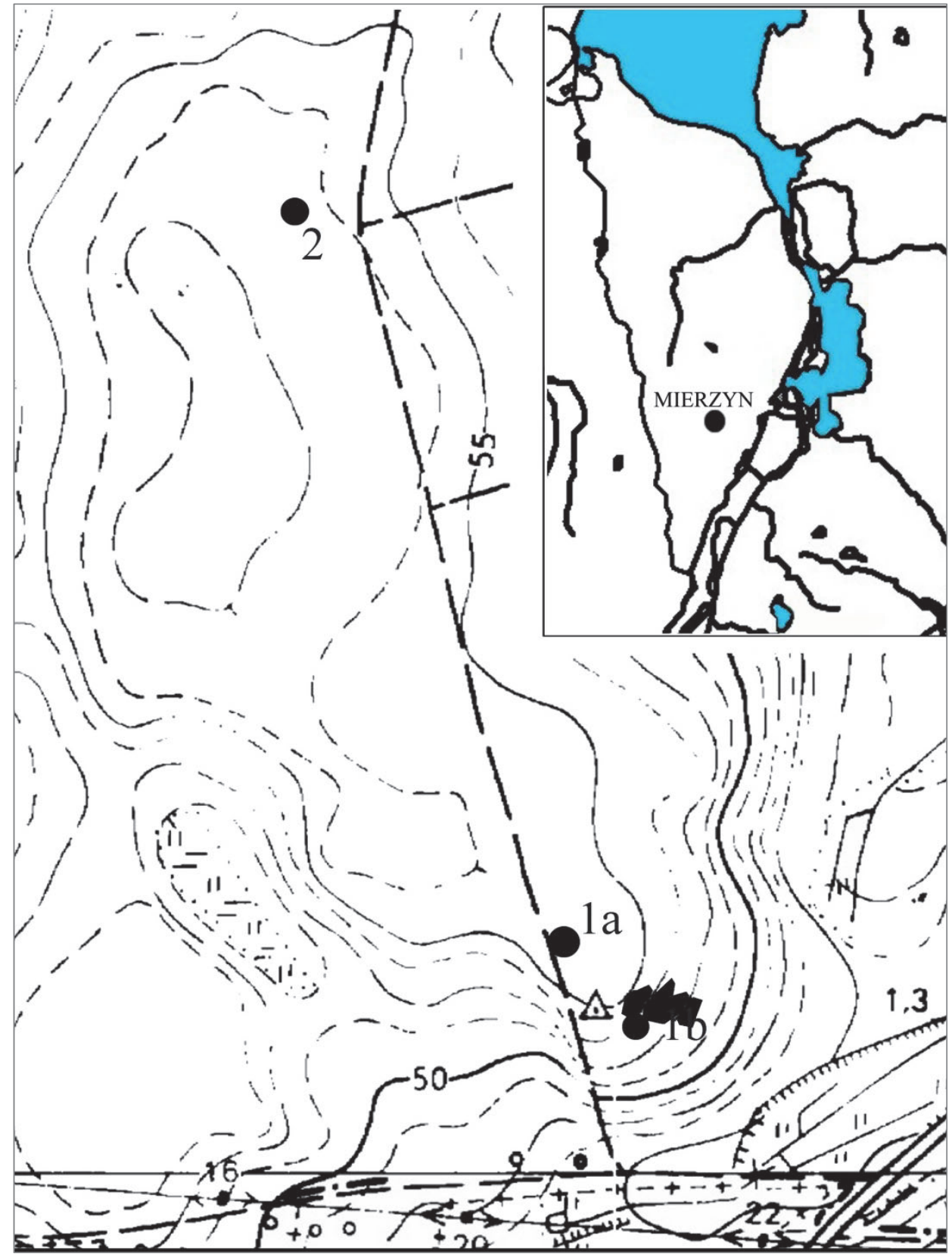

Ryc. 1. Mapa z lokalizacją obiektów na stanowisku nr 4 i 9 w Mierzynie: 1a - obiekt badany w 2004 r.; 1b - obiekt odkryty w 2007 r.; 2 - obiekt badany w 2010 r. Wyk. M. Dziewanowski

Fig. 1. Map showing the location of features at sites 4 and 9 in Mierzyn: 1a - feature excavated in 2004; $1 \mathrm{~b}$ - feature discovered in 2007; 2 - feature excavated in 2010. Prepared by M. Dziewanowski 
Stanowisko $\mathrm{nr} 4 \mathrm{w}$ Mierzynie uznano za wartościowe po zidentyfikowaniu w kolekcji H. Bollnowa fragmentu naczynia ostrodennego, łączonego z kulturą wczesnoneolityczną. Wówczas było to pierwsze takie znalezisko na Pomorzu Zachodnim. Luźny charakter znaleziska i jego fragmentaryczny stan zachowania uniemożliwiał podjęcie szczegółowej dyskusji nad chronologią i atrybucją kulturową wyrobu (ryc. 1). Najnowsze świadectwa osadnictwa udokumentowane w trakcie prac zrealizowanych w 2004 r. skłaniają do prezentacji materiałów zabytkowych pozyskanych w trakcie badań sondażowych na stanowisku nr 4 w Mierzynie.

\section{LOKALIZACJA STANOWISKA NR 4 W MIERZYNIE (AZP 30-04/54)}

Stanowisko $\mathrm{nr} 4$ jest położone na garbie terenowym zlokalizowanym w obrębie Wału Stobniańskiego, stanowiącego podjednostkę klasyfikacyjną w ramach Wzniesień Szczecińskich (Borówka 2002, ryc. 1, 14). Zajmuje ono południową część rozległego wzniesienia zlokalizowanego na osi północ-południe (ryc. 1). Powierzchnia kulminacyjnej części wzniesienia zbudowanej z glin przykrytych strefowo utworami murszowymi jest lekko pofalowana. Najwyższy punkt w obrębie stanowiska nr 4 znajduje się na wysokości 55,2 m n.p.m. Południowy stok jest zbudowany z glin morenowych przykrytych warstwą piasku.

Materiał zabytkowy występuje na powierzchni części kulminacyjnej zbudowanej z gliny w niewielkich ilościach gliniastej. W części stokowej zbudowanej z piasku stwierdzono obfite występowanie świadectw działalności gospodarczej w postaci skupisk ceramiki naczyniowej i wyrobów krzemiennych oraz przepalonych kamieni.

\section{HISTORIA BADAŃ STANOWISK NEOLITYCZNYCH NA WALE STOBNIAŃSKIM}

Podstawowe dane o mierzyńskim skupisku osadniczym zawdzięczamy badaczom działającym w okresach akcji budowlanych. W drugiej połowie XIX i na początku XX w. nastąpiła modernizacja pomorskich wsi, czego efektem były m.in. liczne odkrycia archeologiczne. Podczas budowy sieci trakcji kolejowych i dróg na terenie Prus prowadzono liczne prace geodezyjne i kartograficzne. Towarzyszyły im „dozory” i prace inwentaryzacyjne, realizowane zarówno przez miejscowych miłośników historii „małej ojczyzny”, jak również przedstawicieli administracji publicznej. Z tego okresu posiadamy informacje o znaleziskach ze środkowej i młodszej epoki kamienia z sąsiednich miejscowości: Dołuje, Barnisław i Skarbimierzyce (Siuchniński 1969, s. 145, 147, 157). Na przełomie XIX i XX w. poszukiwania prowadzili przede wszystkim Hugo Lemcke, dyrektor Towarzystwa Historii i Starożyt- 
ności Pomorza, i konserwator Adolf Stubenrauch. W pracach dokumentacyjnych uczestniczył geolog Gottfried Müller, znany ze swoich odkryć dokonanych nad Jeziorem Weltyńskim (Dziewanowski 2012b).

W latach dwudziestych XX w. poszukiwania w okolicach miejscowości Mierzyn prowadził nauczyciel Blessin. W latach trzydziestych natomiast na terenie całego powiatu miały miejsce intensywne prace ziemne związane $\mathrm{z}$ budową rozległych osiedli domków jednorodzinnych i szeregowców, którym towarzyszyły liczne prace mające na celu modernizację oraz budowę nowych dróg. W tym okresie powstały m.in. rozległe osiedla w Mierzynie, Szczecinie-Świerczewie i Szczecinie-Gumieńcach (Luczak 2006, s. 14).

Pierwszy okres badań stanowiska nr 4 w Mierzynie przypada na lata 1929-1945 i jest związany z dwoma badaczami niemieckimi. Stanowisko zostało odkryte w 1929 r. w wyniku prospekcji terenowych przeprowadzonych przez Hermanna Bollnowa. Zakres działań wskazanych w notatkach archiwalnych świadczy o znacznej wiedzy archeologicznej znalazcy, jednak nie dysponujemy danymi ukazującymi tło inicjatywy badawczej, której efektem było odkrycie. W rezultacie poszukiwań powstał zbiór złożony z kilkudziesięciu fragmentów ceramiki, kilku wyrobów krzemiennych i fragmentu siekiery kamiennej tzw. Walzenbeil. Bezpośrednio po poinformowaniu archeologów o odkryciu, fragment naczynia ostrodennego stał się obiektem zainteresowania Pomersches Landesmuseum. Przypuszczano bowiem słusznie, że może być on związany z kulturą wczesnoneolityczną. Według notatki zamieszczonej w teczce archiwalnej nr 1721 (Möhringen) ${ }^{1}$ w skład kolekcji wchodziły również dwa naczynia. Od 1932 r. dalsze poszukiwania na tym terenie prowadził Richard Richter, jednak w trakcie kwerendy zasobów Muzeum Narodowego w Szczecinie nie stwierdzono świadectw (notatek, metryczek lub kartoników) sugerujących zbieranie przez tego badacza artefaktów z powierzchni stanowiska.

W latach 1945-1983 prowadzono badania nad klasyfikacją kulturowo-przestrzenną kultur neolitycznych. Kluczową postacią w tym okresie był Kazimierz Siuchniński, który od końca lat pięćdziesiątych XX w. realizował program badań na terenie Pomorza Zachodniego. W trakcie badań terenowych przeprowadzonych w $1961 \mathrm{r}$. rozpoznał na powierzchni wzniesienia pozostałości licznych palenisk oraz skupiska ceramiki i krzemieni. Pozyskał jednak nieliczny zbiór materiału wyrobów i fragmentów naczyń. Zaobserwowane wówczas silnie zerodowanie podłoża, w wyniku wieloletnich prac agrotechnicznych, było przyczyną niskiej oceny wartości poznawczej stanowiska (Siuchniński 1961, s. 782; 1983, s. 261).

Stanowisko w Mierzynie ponownie stało się przedmiotem prac archeologicznych w 1983 r., w wyniku podjęcia ogólnopolskiej akcji Archeologicznego Zdjęcia Polski. Przeprowadzono wówczas badania powierzchniowe, które pozwoliły zaewi-

\footnotetext{
${ }^{1}$ Dokumentacja archiwalna jest przechowywana w Archiwum Działu Archeologii Muzeum Narodowego w Szczecinie.
} 
dencjonować stanowisko w krajowym rejestrze zabytków archeologicznych, lecz nie pozyskano nowych znalezisk $\mathrm{w}$ trakcie weryfikacji terenowej.

Pod koniec lat dziewięćdziesiątych XX w. rozpoczęto intensywną zabudowę przedmieść i okolic Szczecina. Nastąpiło wówczas zabudowywanie terenu polegające na uzbrajaniu znacznych powierzchni. W efekcie tych prac naruszono liczne stanowiska archeologiczne. Istniejące na mapach sieci mediów oraz dostępne bezpośredniej percepcji budynki zlokalizowane w obrębie stanowisk i stref ochrony konserwatorskiej $\mathrm{w}$ świetle przeprowadzonej kwerendy nie były objęte nadzorami archeologicznymi. Dokonywane przez współautora tekstu wizytacje stanowisk ujawniały kolejne obiekty kulturowe $\mathrm{z}$ okresu wczesnego i środkowego neolitu (Dziewanowski 2008, 2013; Matuszewska, Dziewanowski 2011).

W trakcie kopania rowów pod media, przecinających różne partie stanowiska, odsłonięto obiekty oraz naruszono warstwy kulturowe zawierające liczny materiał ceramiczny i krzemienny datowany na okres neolitu. W centralnej i południowej partii wzniesienia ujawniono ponadto skupiska materiału zabytkowego zalegającego bezpośrednio $\mathrm{w}$ warstwie humusu.

W 2002 r. w trakcie wykonywania wykopów liniowych pod media odsłonięte zostały obiekty i nawarstwienia archeologiczne, zaś rok później podjęto przygotowania do interwencyjnego zadokumentowania jednego obiektu. W ramach współpracy między IP UAM w Poznaniu i Muzeum Narodowym w Szczecinie w 2004 r. przeprowadzono badania ratunkowe pod kierunkiem T. Galińskiego. Poza autorami tekstu w badaniach na stanowisku nr 4 w Mierzynie uczestniczyli studenci: Damian Piłaszewicz, Bogusław Stawniak, Michał Rejchert, Arkadiusz Klimowicz, Patrycja Jakubczyk. W pracach brał udział również sympatyk archeologii Marek Piłaszewicz.

W latach 2003-2006 autor wielokrotnie obserwował prace ziemne związane z budową osiedla, pozyskując z odsłoniętych obiektów i warstw kulturowych 1250 wyrobów krzemiennych i liczny zbiór ceramiki naczyniowej z różnych części stanowiska. Na kolekcję składają się fragmenty siekier, odłupki z siekier gładzonych, produkty eksploatacji wiórowej, narzędzia i inne wyroby krzemienne. Powiększono również zbiór fragmentów naczyń ceramicznych, reprezentujących różne fazy zasiedlenia stanowiska w okresie neolitu (tab. 1).

W 2007 r. w trakcie dozoru ${ }^{2}$ zaobserwowano liczne fragmenty ceramiki i wyroby krzemienne wypłukane ze stropowej części obiektu odsłoniętego w wyniku intensywnych opadów deszczu. Dla dalszych studiów gabinetowych i działań konserwatorskich zabezpieczono 79 wyrobów krzemiennych oraz 201 fragmentów ceramiki. W zbiorze zidentyfikowano fragment masywnej siekiery krzemiennej typu Viervitz oraz odpady z produkcji i modyfikacji siekier.

\footnotetext{
${ }^{2}$ Termin „dozór” opisuje działania służące dokumentacji naruszanych świadectw osadnictwa pradziejowego, podejmowane wobec braku możliwości przeprowadzenia nadzorów archeologicznych.
} 
Tabela 1. Mierzyn stan. 4. Porównanie danych ilościowych kolekcji pozyskanych na stanowisku nr 4 $\mathrm{z}$ różnych kontekstów stratygraficznych. W nawiasie podano sugerowaną chronologię w systematyce skandynawskiej

Table 1. Mierzyn site 4. Comparison of quantitative data of collections recovered from various stratigraphic contexts at site 4. Suggested chronology according to Scandinavian system is given in brackets

\begin{tabular}{|l|c|c|c|c|c|c|}
\hline \multicolumn{7}{|c|}{ Porównanie ilościowe zbiorów ze stanowiska nr 4 w Mierzynie } \\
\hline & $\begin{array}{c}\text { Obiekt KPL (EN C-MN I?) } \\
\text { Badania w 2004 r. }\end{array}$ & $\begin{array}{c}\text { Powierzchnia (EK-EB) } \\
\text { Odkrycia w 2005 r. }\end{array}$ & $\begin{array}{c}\text { Obiekt KPL/KAK (I-II MN) } \\
\text { Odkrycia w 2007 r. }\end{array}$ \\
\hline Typ znalezisk & Liczba & $\%$ & Liczba & $\%$ & Liczba & $\%$ \\
\hline Narzędzia & 5 & 9,25 & 135 & 19,7 & 25 & 31,6 \\
\hline Wiórowe & 1 & 1,9 & 82 & 12 & 14 & 17,7 \\
\hline Siekiery & 0 & 0 & 25 & 3,7 & 5 & 6,3 \\
\hline Wielościenne & 10 & 18,5 & 158 & 23 & 5 & 6,3 \\
\hline Luszczniowe & 1 & 1,9 & 162 & 23,7 & 5 & 6,3 \\
\hline Suma & 54 & 100 & 684 & 100 & 79 & 100 \\
\hline
\end{tabular}

\section{ZNALEZISKA HERMANNA BOLLNOWA (A/6156) I ICH INTERPRETACJA}

Znaleziska ceramiczne „ugrupowań leśnych” znajdują się w zbiorach Muzeum Narodowego w Szczecinie pod numerem inwentarza A/6156M.

Pierwsza wzmianka o odkryciu wraz z interpretacją znaleziska została zamieszczona w 1934 r. w czasopiśmie Altschlesien w kontekście rozważań Bolko von Richthofena o znaleziskach ceramiki dołkowo-grzebykowej na terenie Śląska, łączonych z kręgiem północno-eurazjatyckim (Richthofen 1934, Taf. 9.3, 9.6.).

W 1958 r. ukazał się pierwszy polski artykuł uwzględniający znaleziska z Mierzyna autorstwa Aleksandra Gardawskiego pt. „Zagadnienie kultury «ceramiki grzebykowej» w Polsce", którą skojarzył z kulturą dnieprowko-łabiańską (kulturą ceramiki grzebykowej). Fenomen ugrupowań wschodnich figurujących pod pojęciem „kultury prafińskiej” lub „kultury ceramiki grzebykowej” stanowił wówczas dość atrakcyjne zagadnienie. W ramach studiów kulturowo-chronologicznych historia społeczności łowiecko-zbierackich funkcjonujących równolegle z kulturami neolitycznymi stanowiła od 30 lat szczególnie istotny przedmiot studiów archeologicznych. W tekście zamieszczono fotografie 5 fragmentów ceramiki z kolekcji H. Bollnowa (Möhringen, pow. rędowski lub pow. Rędów, Gardawski 1958, ryc. 1-2), które aktualnie można określić jako: jeden fragment naczynia ostrodennego (ryc. 2:1), dwa fragmenty naczyń nieokreślonej kultury neolitycznej (ryc. 2:2,3) oraz dwa fragmenty naczyń kultury ceramiki sznurowej z różnych faz w ramach tych jednostek kulturowych. W tej konwencji zdobienie jodełek pionowych określono jako „rybia ość” (Gardawski 1958, s. 292). Dla podjętych rozważań zdaje się być istotna sugestia o przynależności fragmentu naczynia ostrodennego do starszej fazy kultury 

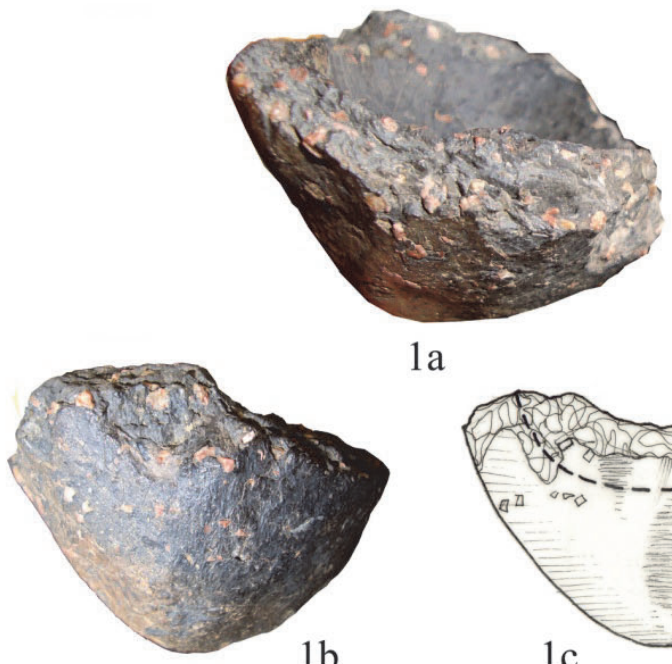

$1 \mathrm{a}$
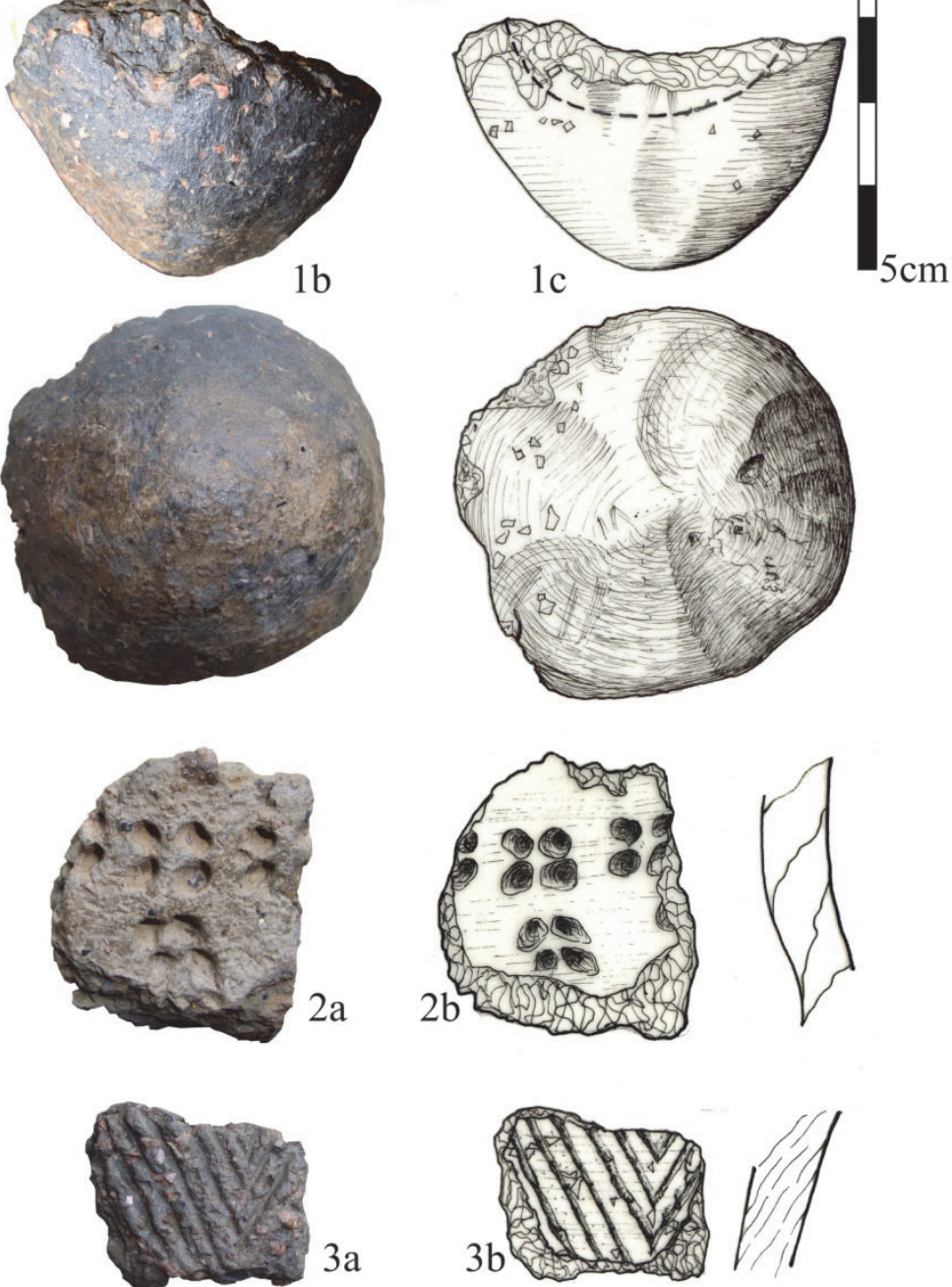

$3 a$

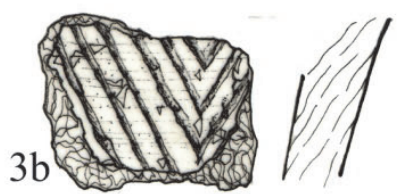

Ryc. 2. Mierzyn, stan. 4. Wybór znalezisk H. Bollnowa z 1929 r. Zbiory Muzeum Narodowego w Szczecinie. Wyk. M. Dziewanowski

Fig. 2. Mierzyn, site 4. Selection of H. Bollnow's 1929 finds. Collection of the National Museum in Szczecin. Prepared by M. Dziewanowski 
ceramiki grzebykowej. Uzależnianie wartości znaleziska dla studiów i oceny jednorodności chronologicznej zespołu od informacji, czy materiał pozyskali tzw. amatorzy-archeolodzy jest charakterystyczne dla nurtu kulturowo-historycznego (Gardawski 1958, s. 292). W różnych częściach opracowania omawiane znaleziska z Mierzyna figurują pod pojęciem starszej i młodszej kultury dnieprowskołabiańskiej. Znaleziska przypisane do starszej fazy osadniczej można łączyć z kulturą pucharów lejkowatych i starszymi fazami kultury ceramiki sznurowej, zaś młodsze z kulturą ceramiki sznurowej.

Kazimierz Siuchniński na podstawie kolekcji fragmentów naczyń ceramicznych z kilku skupisk osadniczych i kilkunastu stanowisk z Pomorza Zachodniego wykazał zasadność podjęcia tematu tzw. kultury dołkowo-grzebykowej (Siuchniński 1972, s. 123), włączanej wówczas do zagadnienia tzw. subneolitu. Naczynie ostrodenne z Mierzyna zostało ogólnie skojarzone z bliżej nieokreślonymi wczesnymi stadiami rozwojowymi kultury tej formacji. Badacz wskazywał szereg znalezisk ceramicznych koncentrujących się m.in. w strefie mierzyńskiej, które sugerowały istnienie mieszanych, krótkotrwałych grup o dominujących cechach KCDG (Siuchniński 1983, s. 142). Według Tadeusza Wiślańskiego istnieją dwa skupiska osad kultury dołkowo-grzebykowej w strefie dolnoodrzańskiej w okolicach Mierzyna i Goleniowa (Wiślański 1979, ryc. 195).

W wyniku rozważań Macieja Czarneckiego fragment naczynia ostrodennego ze stanowiska nr 4 w Mierzynie zaczęto łączyć ze zjawiskiem ceramicznej fazy rozwojowej ugrupowań technokompleksu Ertebølle-Ellerbek, klasyfikowanych jako „mezolit ceramiczny"3 (Czarnecki 1981, s. 345-354). Według rozważań przedstawionych w monografii Dzieje Szczecina (Czarnecki 1983, s. 90-92, ryc. 34) kolejnymi świadectwami osadnictwa postmezolitycznego w tej strefie miały być wysmukłe trapezy ze stanowiska nr 5 w Mierzynie (Czarnecki 1983, s. 77, ryc. 34; Dziewanowski 2013). Wskazane znaleziska były umieszczane w przedziale 3600-3200 bc (4400-4000 BC), co odpowiada horyzontowi późnorösseńskiemu, wczesnopucharowemu i wczesnomichelsberskiemu. Wielokrotnie sugerowane istnienie nierozpoznanego osadnictwa wstęgowego na terenie Wału Stobniańskiego nakłania do formułowania pytań o przebieg zmian kulturowych i złożoność dostępnych inwentarzy. Aktualnie dysponuje się danymi o istnieniu intensywnej działalności gospodarczej w V tysiącleciu p.n.e. na terenie Wału Stobniańskiego (Dziewanowski 2013, s. 11-38).

Dobrochna Jankowska w syntezie poświęconej neolityzacji pobrzeża południowo-zachodniobałtyckiego umieściła okaz ceramiki ostrodennej z Mierzyna (1990, ryc. 21.2) na tablicy z wyborem form ceramicznych kultury Ertebølle-Ellerbek (Rosenhof, Ringkloster i Dyrholm II). W późniejszym opracowaniu autorka wskazała

\footnotetext{
${ }^{3}$ Intensywną dyskusję źródłoznawczą i terminologiczną na ten temat prowadzono w latach osiemdziesiątych i dziewięćdziesiątych XX w. (Cyrek, Grygiel, Nowak 1983; Galiński 1991; Kobusiewicz, Kabaciński 1993; Gumiński 1999).
} 
zabytek jako źródło dla rozważań nad udziałem komponentu „leśnego” w neolicie Pomorza (Jankowska 2001, s. 85). W podsumowaniu autorka stwierdziła, że w przypadku elementów północno-wschodnich w strefie Dolnego Nadodrza można mieć do czynienia co najwyżej z bardzo dalekimi reminiscencjami tej stylistyki widocznymi w środowisku KPL i KCSZ (Jankowska 2001, s. 95).

Tadeusz Galiński po przeprowadzeniu studiów nad ceramiką typu Ertebølle ze stanowiska w Tanowie zauważył odmienność technologiczną okazu z Mierzyna, zbliżoną jednak do II grupy technologicznej, którą wydzielił przez siebie, bazując na studiach materiałów protoneolitycznych z tego stanowiska (Galiński 1987, s. 9, 23). W publikacji z 1997 r. na podstawie koloru powierzchni zasugerował odkrycie tego wyrobu w torfie, a więc poza stanowiskiem nr 4 (Galiński 1997, s. 69, mapa 1.15). W najnowszym ujęciu dolnoodrzańskie zespoły protoneolityczne z ceramiką ostrodenną funkcjonowały w okresie 3500-3100 bc (Galiński 1997, s. 76; 2005, s. 88). Zgodnie z tendencją wyników kalibracji dat radiowęglowych wskazany przedział odpowiadałby okresowi 4300-3900 BC. Specyfikę warsztatu studiów nad ceramiką T. Galińskiego $(1992,2005)$ ujawnia sposób zaznaczania śladów czynności technicznych zgodnie z tradycją badaczy kultur protoneolitycznych. Systematyka opisu odnosi się do trójdzielnego ewolucyjnego podziału (Galiński 1992, s. 88).

\section{NOWE ZNALEZISKA Z 2004 R. ZE STANOWISKA 4 W MIERZYNIE (OBIEKT KULTURY PUCHARÓW LEJKOWATYCH)}

W latach 2002 i 2003 zabezpieczono informacje o lokalizacji obiektów naruszonych w trakcie instalacji sieci mediów (ryc. 3), co umożliwiło w 2004 r. precyzyjne założenie wykopu sondażowego (Dziewanowski 2008). W trakcie prac interwencyjnych odsłonięto strop całego obiektu nr 1, który był czytelny już w spągu warstwy ornej o miąższości około $35 \mathrm{~cm}$. Jama miała zarys zbliżony do nieregularnego owalu o orientacji zachód-wschód i wymiarach $500 \times 400 \mathrm{~cm}$ stwierdzonych na poziomie stropu. Szczegółowymi badaniami w ramach sondażu o wymiarach $200 \times 300 \mathrm{~cm}$ objęto zachodnią część jamy, naruszonej przez wkop pod media (ryc. 4). Maksymalna miąższość nawarstwień dochodziła do $100 \mathrm{~cm}$. Materiał zabytkowy namierzano w obrębie wykopu z dokładnością do ćwiartki metra, zaś wydzielone znaleziska dokumentowano trójwymiarowo. W obrębie wypełniska jamy w części środkowej wykopu stwierdzono kolistą koncentrację okruchów skalnych i otoczaków, które były każdorazowo niwelowane.

W trakcie eksploracji na głębokości $40 \mathrm{~cm}$, przy północnej ścianie w zasypisku jamy mieszkalnej, stwierdzono strefę o zwiększonej zawartości pylastej spalenizny i koncentrację węgli drzewnych, opisaną jako obiekt 1a. Niestety relacja stratygraficzna między zasypiskiem a soczewką spalenizny nie została sprecyzowana z powodu silnego przekształcenia wypełniska przez procesy podepozycyjne. 

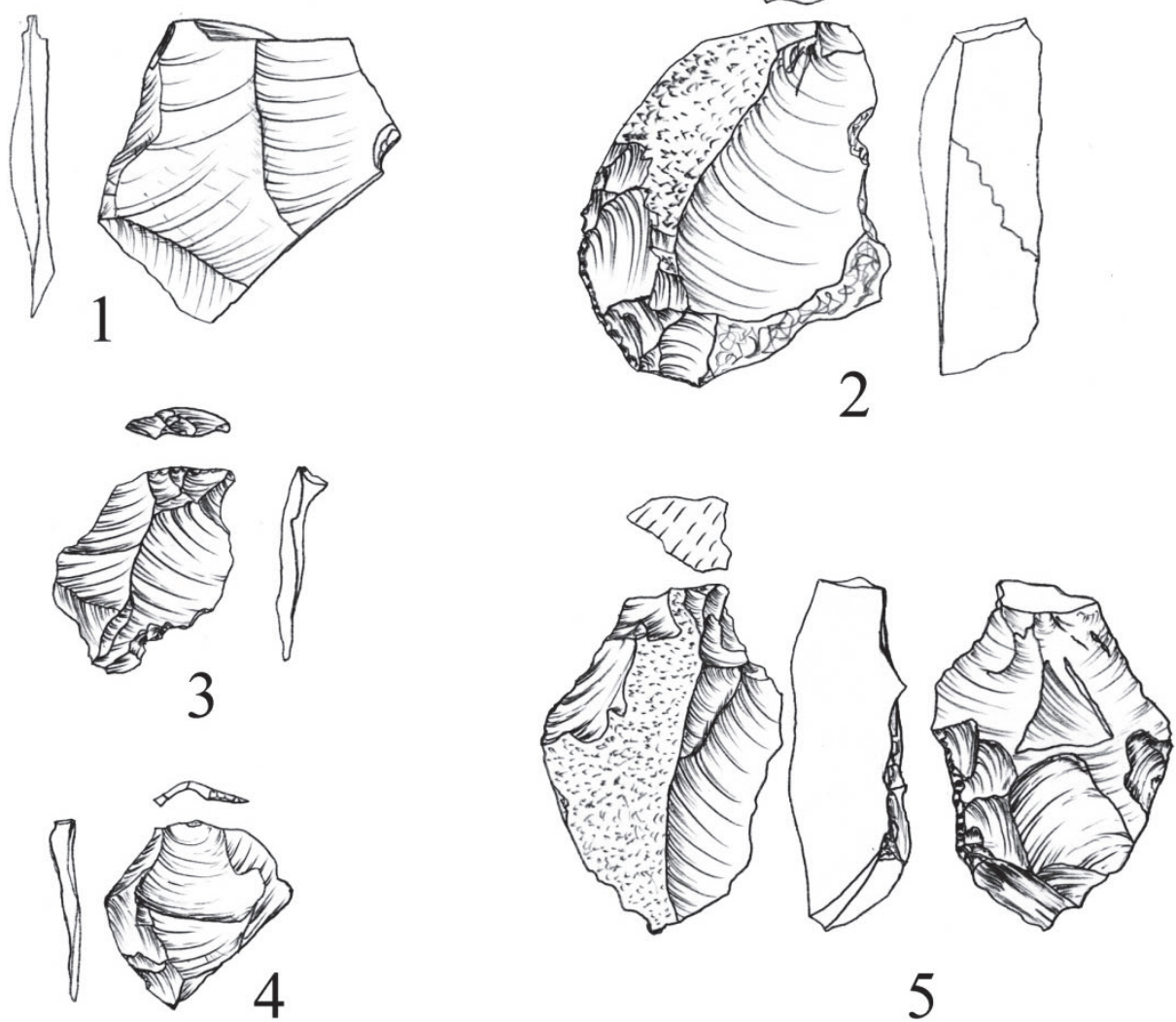

\section{5}
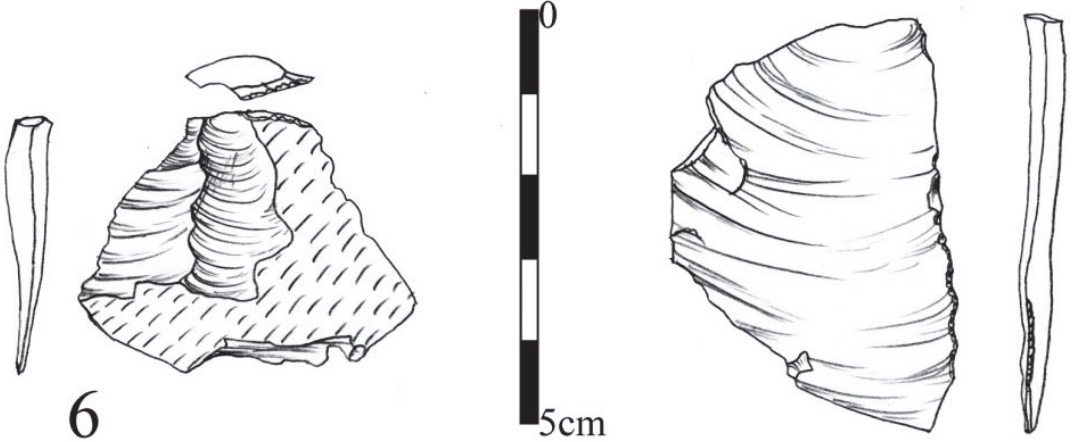

7

Ryc. 3. Mierzyn, stan. 4. Wybór wyrobów krzemiennych z hałdy i humusu. Zbiory Muzeum Narodowego w Szczecinie. Wyk. M. Dziewanowski i A. Ryś

Fig. 3. Mierzyn, site 4. Selected flint artefacts from the spoil heap and humus. Collection of the National Museum in Szczecin. Prepared by M. Dziewanowski and A. Ryś 
Wykop badawczy z 2004 r.

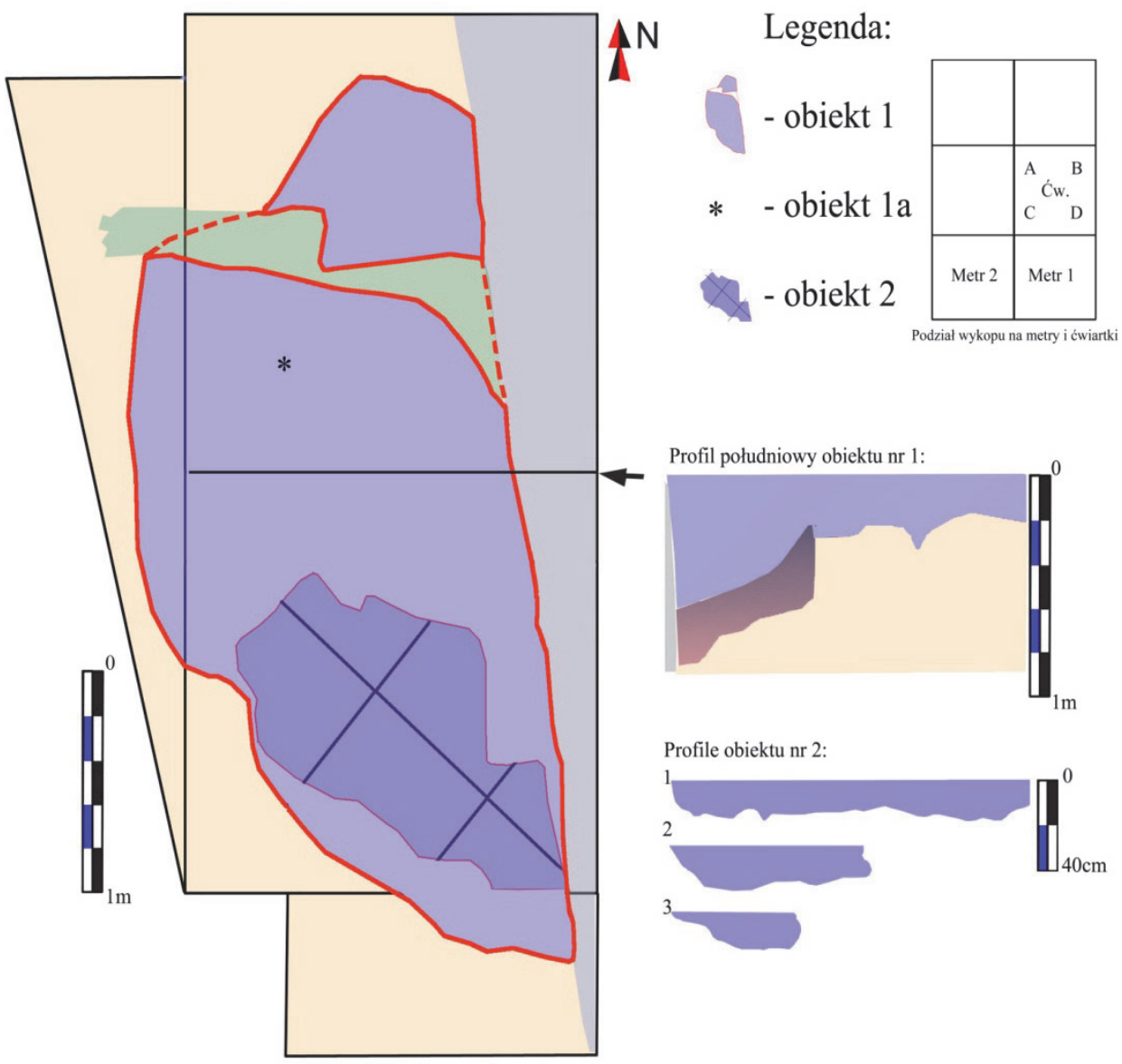

Ryc. 4. Mierzyn, stan. 4. Zestawienie dokumentacji wykopu badawczego z 2004 r. Wyk. M. Dziewanowski

Fig. 4. Mierzyn, site 4. Documentation from the 2004 trench. Prepared by M. Dziewanowski

W południowo-wschodniej części wykopu, pod zasypiskiem jamy mieszkalnej, stwierdzono jamę gospodarczą (piwniczkę?), będącą stratygraficznie najstarszym świadectwem osadnictwa kultury pucharów lejkowatych. Jama opisana jako obiekt $\mathrm{nr} 2$ posiadała zarys zbliżony do nieregularnego owalu o wymiarach $180 \times 60-100 \mathrm{~cm}$ i głębokości $30 \mathrm{~cm}$ (około $45 \mathrm{~cm}$ poniżej stropu obiektu $\mathrm{nr}$ 1). Wypełnisko jamy tworzyła czarna glina silnie nasycona pylastą spalenizną, węglami drzewnymi i drobnymi, przepalonymi kosteczkami oraz grudkami polepy. 


\section{Znaleziska ceramiczne}

W wyniku prac badawczych pozyskano 395 fragmentów ceramiki. Zdecydowana większość okazów miała wielkość nieprzekraczającą pięciu centymetrów. Fragmentaryczny stan zachowania znalezisk znajduje odzwierciedlenie w ograniczonych możliwościach opisu cech makromorfologicznych. Zaledwie dwa fragmenty noszą ślady klasycznego zdobienia, zaś dwa kolejne mają zdobienie plastyczne (ryc. 5). Prace gabinetowe zrealizowano, inspirując się opracowaniem łupawskiej ceramiki kultury pucharów lejkowatych (Wierzbicki 1999, s. 52-57). Scharakteryzowano całość materiału masowego, uwzględniając grubość ścianek, zabarwienie masy oraz rodzaj domieszki schudzającej.

Szczegółowy opis sporządzony przede wszystkich dla potrzeb dokumentacji muzealnej objął dane technologiczne i metryczne 295 znalezisk. Do opracowania włączono również zbiór z hałdy, złożony z 34 fragmentów ceramiki. Składanie pozwoliło zredukować liczbę jednostek objętych opracowaniem do 276 pozycji w bazie danych (ryc. 5).

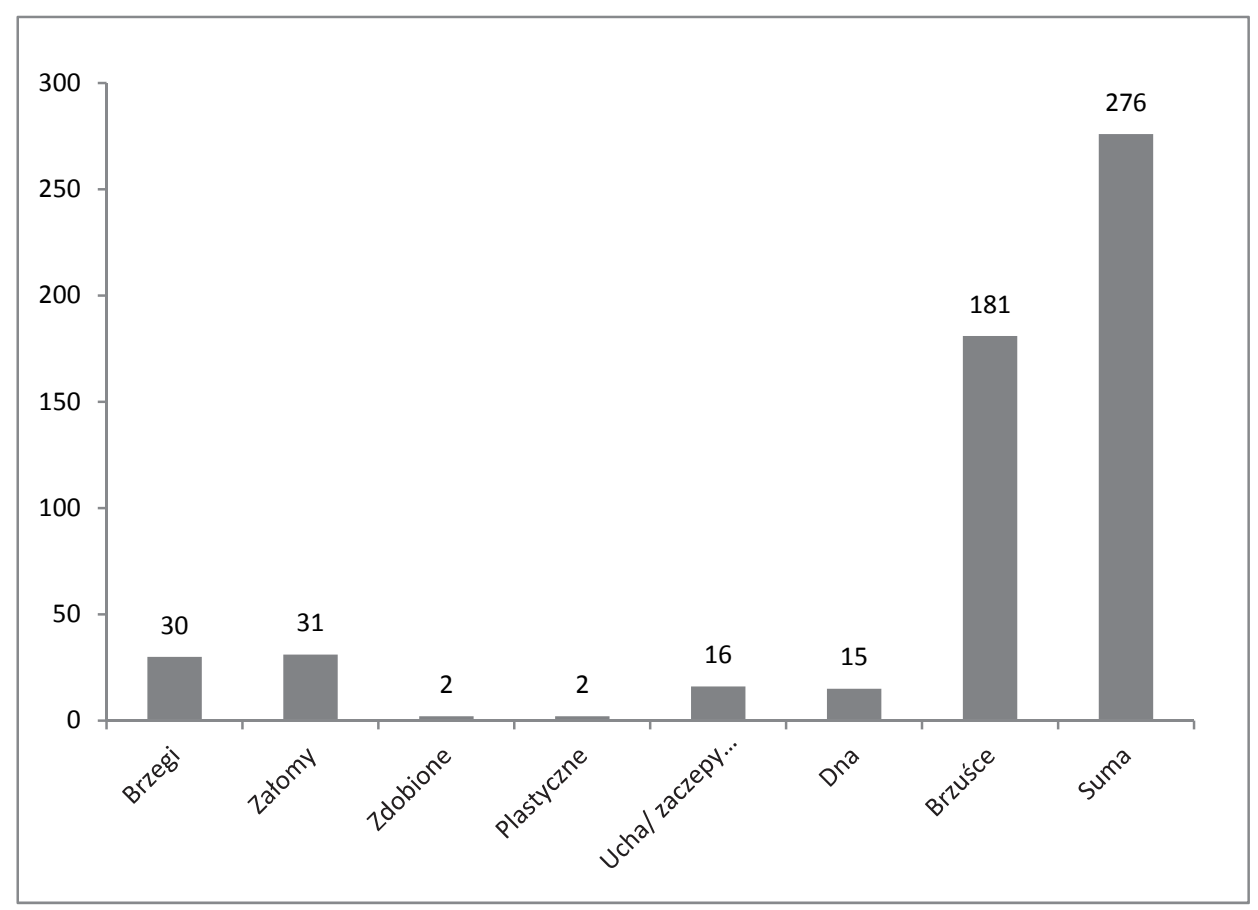

Ryc. 5. Mierzyn stan. 4, obiekt 1 i 2. Prezentacja frekwencji makromorfologicznych cech naczyń ceramicznych. Wyk. M. Dziewanowski

Fig. 5. Mierzyn site 4, features 1 and 2. Frequency of macromorphological features of pottery. Prepared by M. Dziewanowski 
Intensywne wytrącenia substancji ilastych silnie spajające drobiny piasku na powierzchniach utrudniały czytanie cech fragmentów ceramiki. Ze względu na stan zachowania znalezisk lub czytelność cech, w wielu przypadkach nie było możliwe dokonanie pełnej klasyfikacji. Szczegółowo opisano charakterystyczne fragmenty, zaś w osobnym rozdziale omówiono kluczowe wyniki przeprowadzonych studiów technologicznych.

\section{Syntetyzujące omówienie ceramiki naczyniowej}

W kolekcji ceramiki z obiektu nr 1 zidentyfikowano puchary o prostych, pochylonych i silnie pochylonych szyjkach oraz stwierdzono pojedyncze fragmenty pucharów zasobowych, zaopatrzonych w zaczep ucha na przejściu w brzusiec, w tym ucho kolankowe o wyraźnie zarysowanych graniach. Szczególnie interesujące znalezisko stanowi okaz pucharka o łukowato wypukłej szyjce (ryc. 6:1). Najbliższe podobieństwa można odnaleźć w zespołach wczesnych faz kultury ceramiki sznurowej. Zbliżone formy są znane również z zespołów wczesnopucharowych, m.in. ze stanowiska w Parow umieszczanego na przełomie V i IV tysiąclecia BC (Terberger, Seiler 2005, s. 157-162, Abb. 4.5). Silnie pochylone szyjki, w tym o wypukłym, łukowatym profilu stanowią klasyczny element stylistyki grupy południowowschodniej (Kulczycka-Leciejewiczowa 2002, ryc. 8.4, 18, 2, 26.17, 31.8).

W kolekcji stwierdzono również fragmenty szyjek amfor zasobowych o ściankach niemal pionowych. Zanotowano fragment ostro profilowanego naczynia o zakolonym brzuścu, zaopatrzonym w (taśmowate?) ucho (porównaj dzbany baalberskie w opracowaniu Preu $\beta$ 1966) oraz pojedyncze fragmenty naczyń o wyraźnym profilowaniu ze śladami zaczepów taśmowatych uch w okolicy załomu brzuśca. Okazy te można określić jako dzbany. Na uwagę zasługuje częściowo zrekonstruowane naczynie o wyraźnie zaznaczonych załomach (ryc. 6:2), nawiązujące do okazów grupy Gatersleben (Kroitsch 1973, ryc. 2, 10.h, 14.i), jak również wielu form baalberskich (Preu $\beta$ 1966, tab. I.3).

Wyrazisty komponent stanowią misy w odmianach zarówno płytkich, jak również głębokich (ryc. 7:2, 4,6,8). W zbiorze zidentyfikowano pojedyncze fragmenty naczyń misowatych o łukowato wklęsłych, krótkich szyjkach i niemalże prostych, o silnie zwężających się partiach dolnych. Szczególny okaz stanowi misa zrekonstruowana rysunkowo ze specyficzną szamotowo-skaleniową domieszką oraz pogrubieniem brzegu od strony wewnętrznej.

W najstarszym zespole pochodzącym z obiektu nr 2 na uwagę zasługuje współwystępowanie następujących rodzajów naczyń: niewielkiego naczynia ostrodennego (ryc. 8:3), pucharu o silnie pochylonej szyjce z poziomym guzkiem na załomie (ryc. 8:1), szerokootworowego naczynia zasobowego (ryc. 8:6) oraz zasobowej amfory o wydatnym, kolistym brzuścu (ryc. 8:4). Rozpatrując chronologię tego zespołu, 

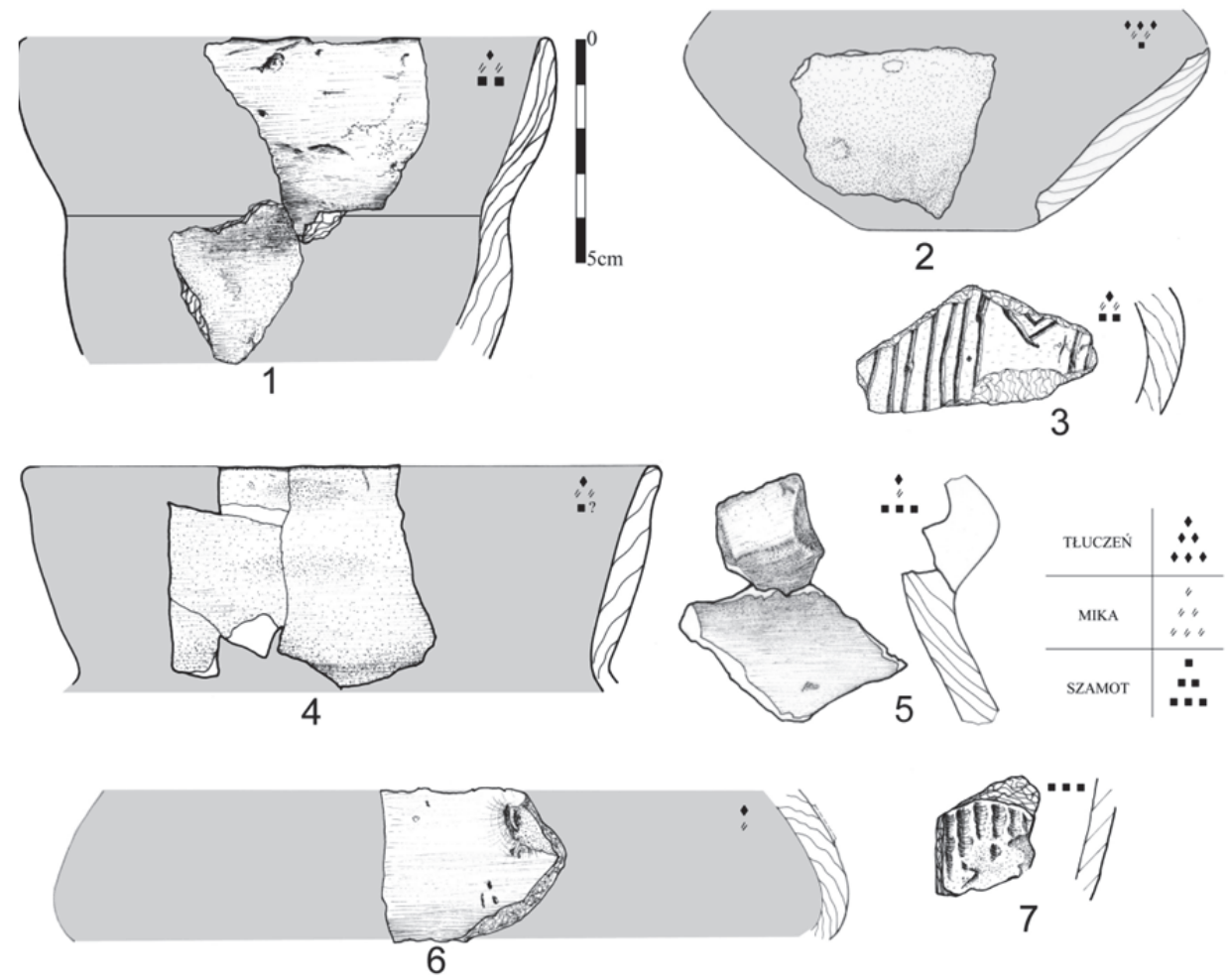

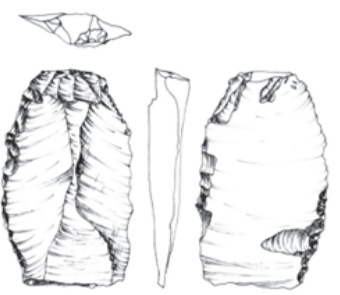

8

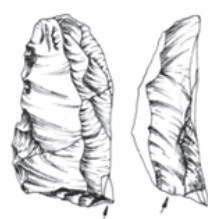

9

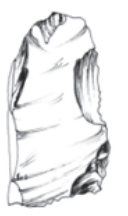

सing
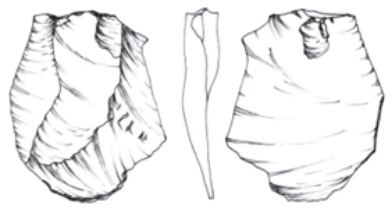

10

Ryc. 6. Wybór znalezisk z wypełniska obiektu nr 1 i obiektu 1a. Zbiory Muzeum Narodowego w Szczecinie. Wyk. M. Dziewanowski i A. Ryś

Fig. 6. Selected finds from fill deposits of feature 1 and feature 1a. Collection of the National Museum in Szczecin. Prepared by M. Dziewanowski and A. Ryś

należy brać pod uwagę cztery horyzonty występowania naczyń ostrodennych. Klasyczne naczynia ostrodenne znane z zespołów protoneolitycznych można umieścić w okresie 4600/4300-4000 BC (Galiński 1997, s. 76; 2005, s. 88; Sobkowiak-Tabaka 2012, s. 23). Kolejne naczynia ostrodenne stanowią puchary typu Pasewalk, które są łączone z wpływami michelsberskimi i datowane na okres 4000/3800-3500 BC (Mende 2001, s. 37; Menke 1988, s. 51; Siuchniński 1972, s. 82; Szmyt 1996, 
s. 266). W horyzoncie ustowskim, charakteryzującym się świadectwami wpływów kultury badeńskiej, możliwe jest występowanie czerpaków i kubków stożkowatych z dużymi uchami wystającymi ponad krawędź (Furholt, Szmyt, Zastawny 2008; Szmyt 2003, fig. 10:3, s. 6, 8, 10; Wiślański 1979, ryc. 187:10). Pomiędzy IV i V okresem środkowego neolitu na wyspach Morza Bałtyckiego występowały klasyczne naczynia ostrodenne związane ze społecznościami subneolitycznymi (Nielsen, Nielsen 1990, fig. 7:b, d, e).

W przebadanej części obiektu wystąpiło niewiele okazów zdobionych. Dominującą formą ornamentowania było nanoszenie w okolicach załomu brzuśca elementów plastycznych, takich jak guzki o zarysie kolistym i zbliżonym do prostokątnego. Wyrazisty element stylistyki stanowi pogrubianie ścianki naczynia tworzące okapy
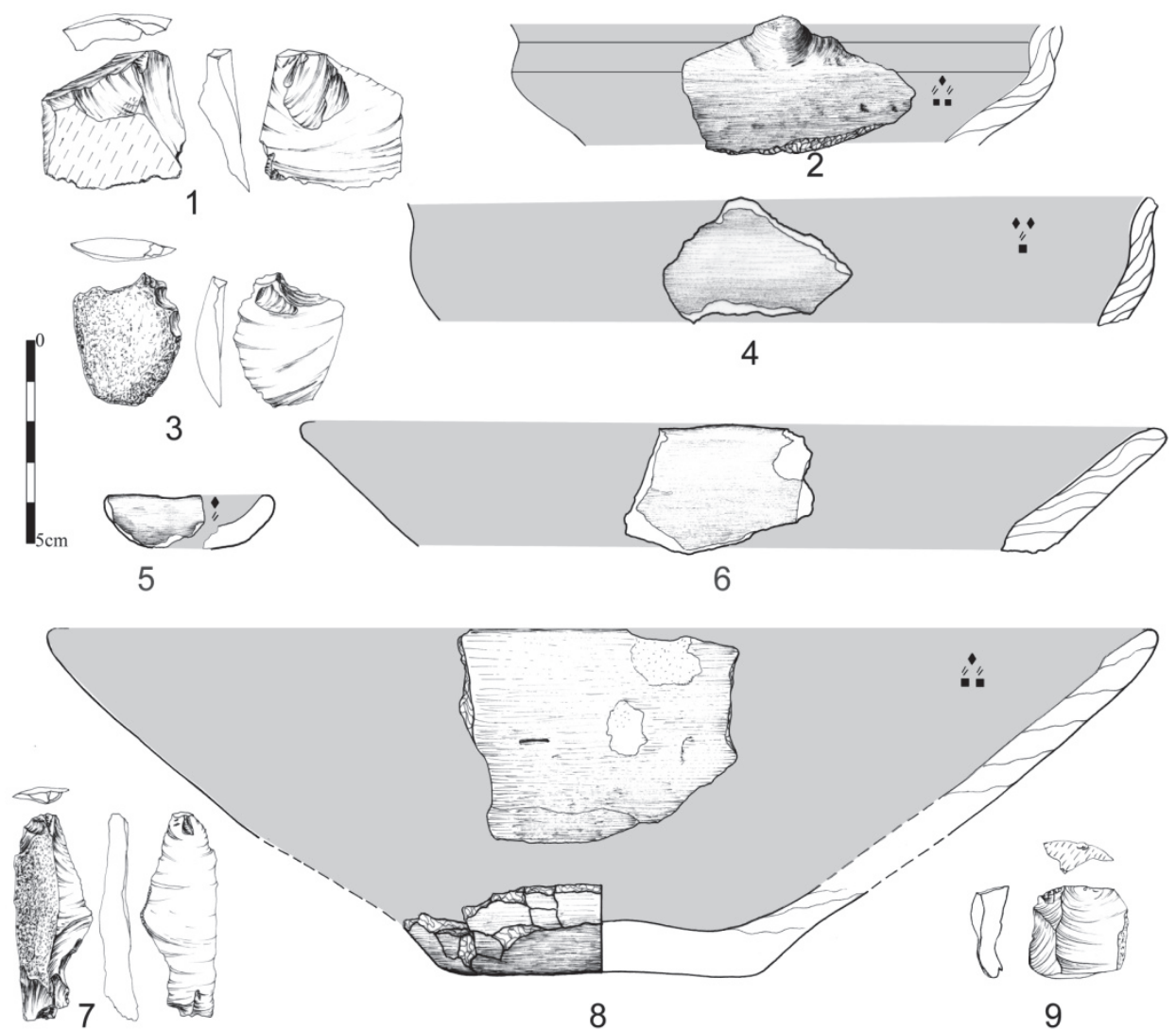

Ryc. 7. Mierzyn, stan. 4. Wybór znalezisk z wypełniska obiektu nr 1. Zbiory Muzeum Narodowego w Szczecinie. Wyk. M. Dziewanowski i A. Ryś

Fig. 7. Mierzyn, site 4. Selected finds from fill deposit of feature 1. Collection of the National Museum in Szczecin. Prepared by M. Dziewanowski and A. Ryś 

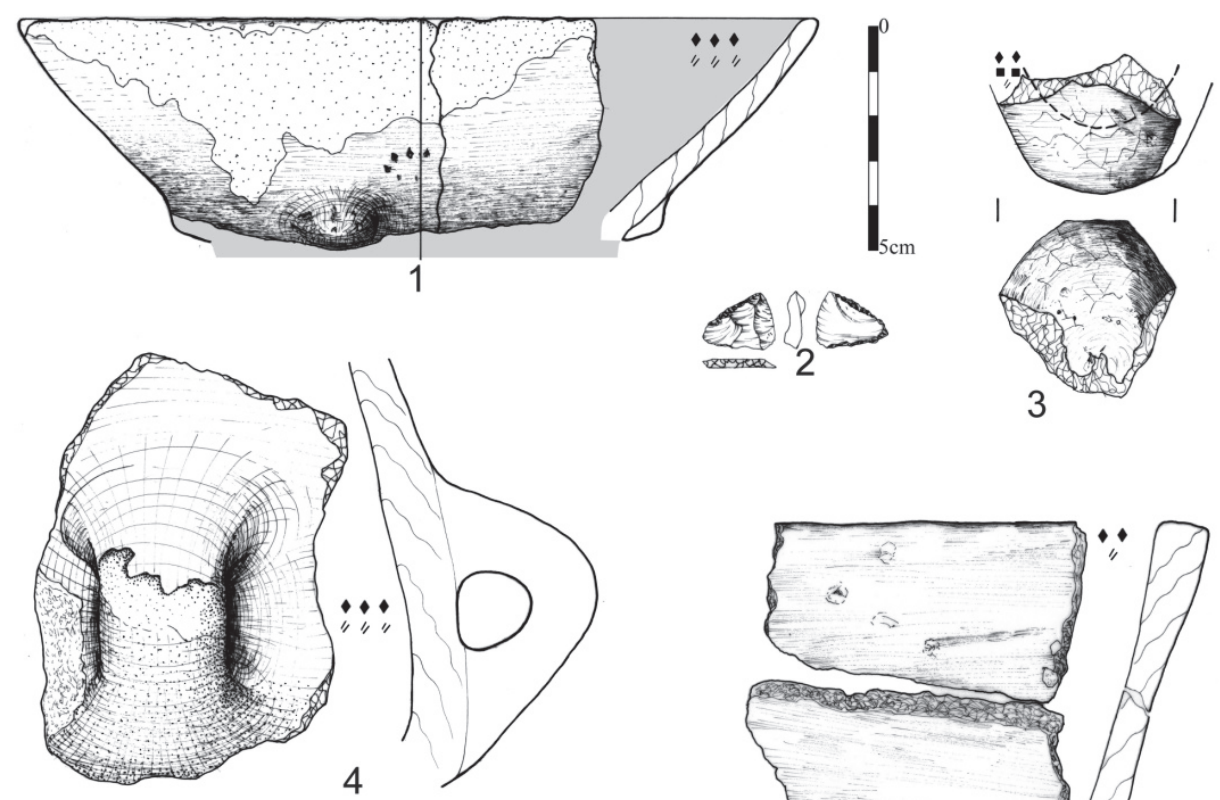

3

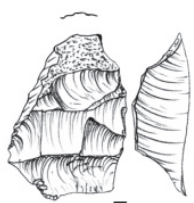

5

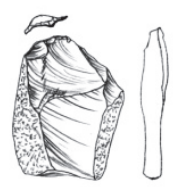

7

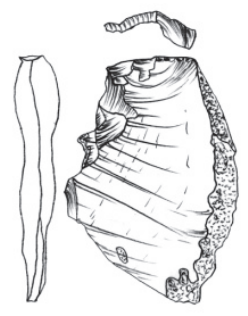

8

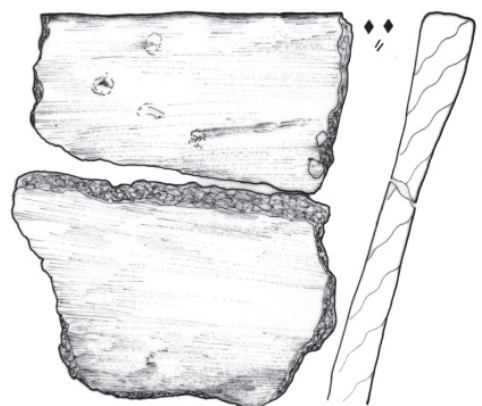

6

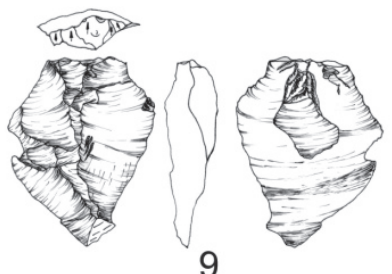

Ryc. 8. Mierzyn, stan. 4. Wybór znalezisk z wypełniska obiektu nr 2. Zbiory Muzeum Narodowego w Szczecinie. Wyk. M. Dziewanowski i A. Ryś

Fig. 8. Mierzyn, site 4. Selected finds from fill deposit of feature 2. Collection of the National Museum in Szczecin. Prepared by M. Dziewanowski and A. Ryś

po stronie wewnętrznej brzegu. Wśród ceramiki naczyniowej pozyskanej z najmłodszej warstwy stwierdzono jedynie dwa fragmenty zdobione techniką rycia. W zasypisku znaleziono niewielki fragment zdobiony szerokimi, pionowymi żłobkami, charakteryzujący się woskową masą, z liczną domieszką drobnego szamotu (ryc. 6:7). Słaby stan zachowania wyjątkowego w tej kolekcji okazu utrudnia jego adekwatne wykorzystanie w studiach porównawczych. W zasypisku jamy półziemiankowej wystąpił również fragment naczynia, którego bark był pokryty piono- 
wymi żłobkami przedzielonymi zwisającymi trójkątami, wykonanymi również w technice rycia (ryc. 6:3).

W kolekcji nieznacznie zaznacza się obecność ceramiki cienkościennej, zaś zdecydowaną większość stanowi ceramika średniościenna (ryc. 9). Wyraźny komponent tworzy również ceramika grubościenna. Największe różnice grubości stwierdzone na jednym fragmencie wynoszą $0,3-0,5 \mathrm{~cm}$.

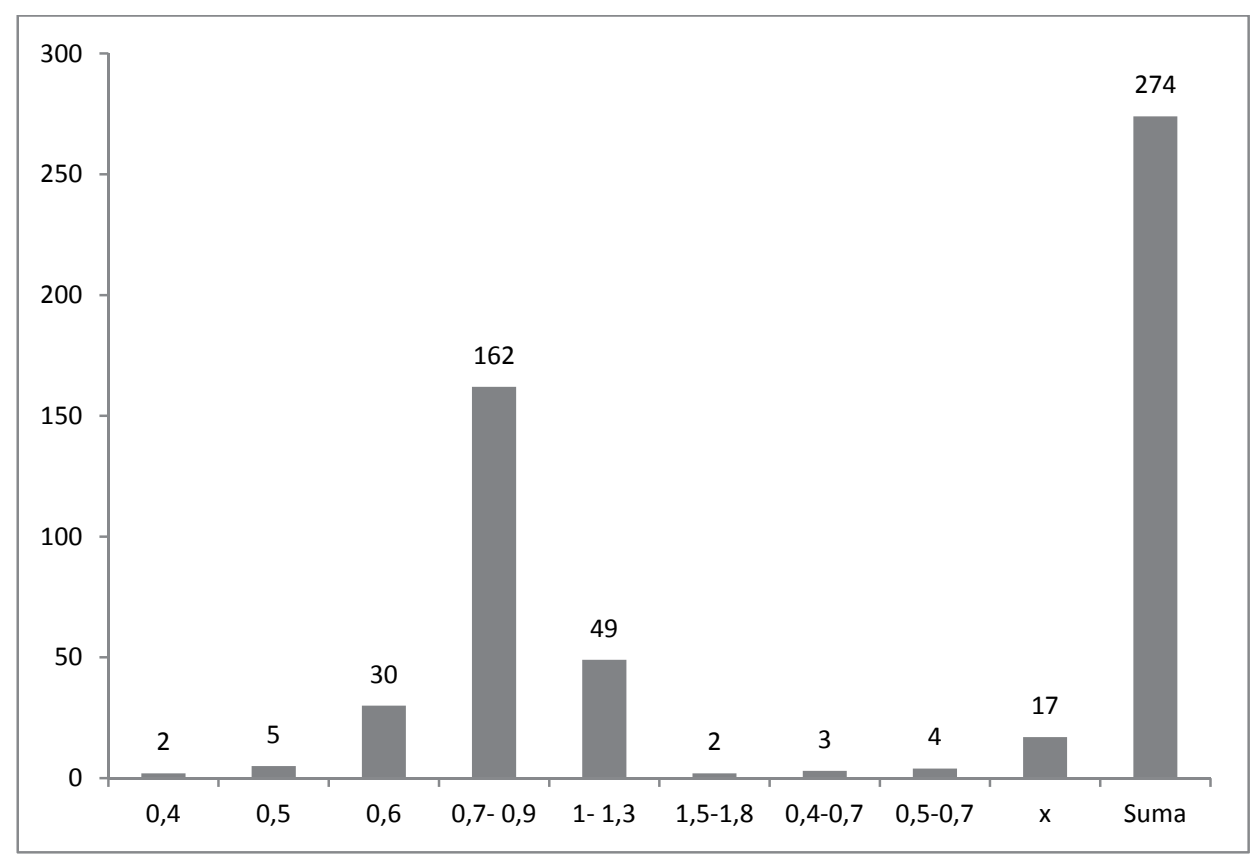

Ryc. 9. Mierzyn stan. 4, obiekt 1 i 2. Prezentacja frekwencji grubości ścianek naczyń ceramicznych. Wartość podana w centymetrach. Wyk. M. Dziewanowski

Fig. 9. Mierzyn site 4, features 1 and 2. Frequency of vessel wall thickness (values in centimetres). Prepared by M. Dziewanowski

Kolekcja ceramiki postrzegana przez pryzmat liczebności i specyfiki uwarstwienia oraz zabarwienia powierzchni i przełamów wykazuje znaczne zróżnicowanie. W zbiorze dostrzegalne są zarówno fragmenty o układzie jedno-, dwu- lub trójwarstwowym, jak również ze strefowym występowaniem warstewki utlenionej na powierzchni zewnętrznej. Najliczniej zaznacza się jednak grupa o dwuwarstwowym przełamie (ryc. 10). Specyficzną cechę technologiczną zbioru zaobserwowaną na wielu fragmentach stanowi nieco jaśniejsze, ciemnobrązowobrunatne zabarwienie środkowej części przełamu niż czarnawych i czarnych powierzchni zewnętrznych i wewnętrznych. 


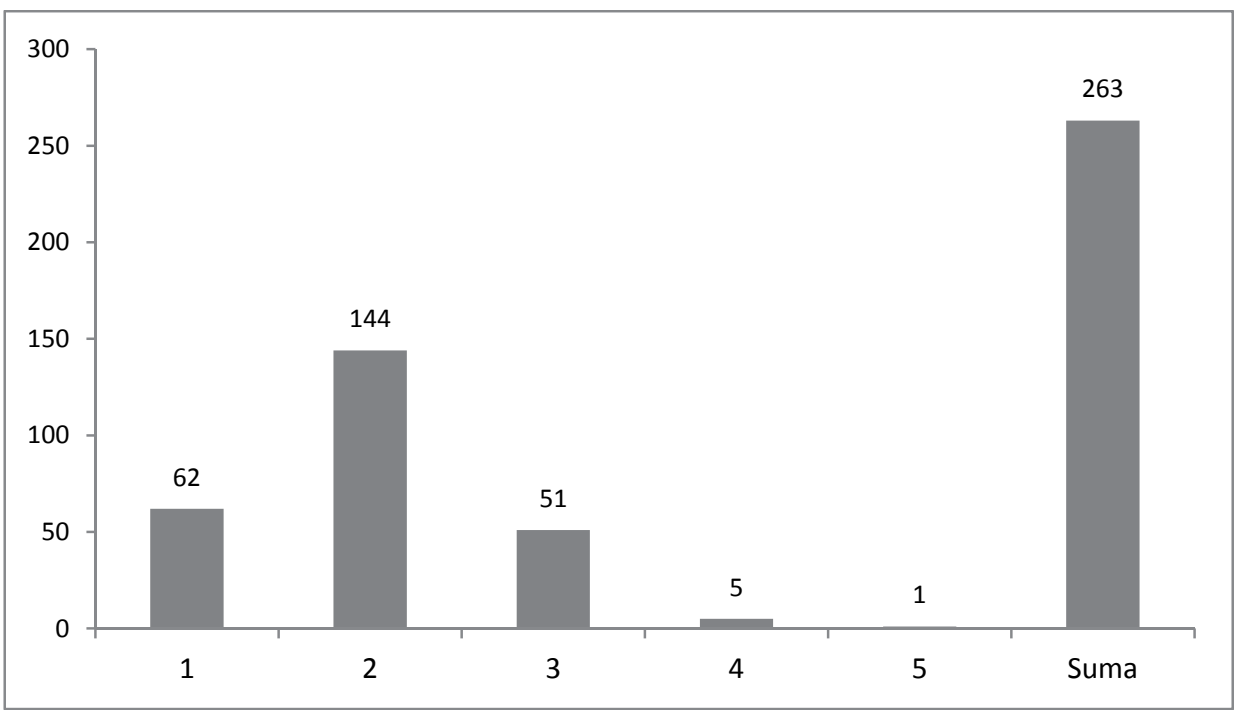

Ryc. 10. Mierzyn stan. 4, obiekt 1 i 2. Prezentacja frekwencji liczby warstw widocznych w przełamach. Wyk. M. Dziewanowski

Fig. 10. Mierzyn site 4, features 1 and 2. Frequency of the number of layers visible in fractures. Prepared by M. Dziewanowski

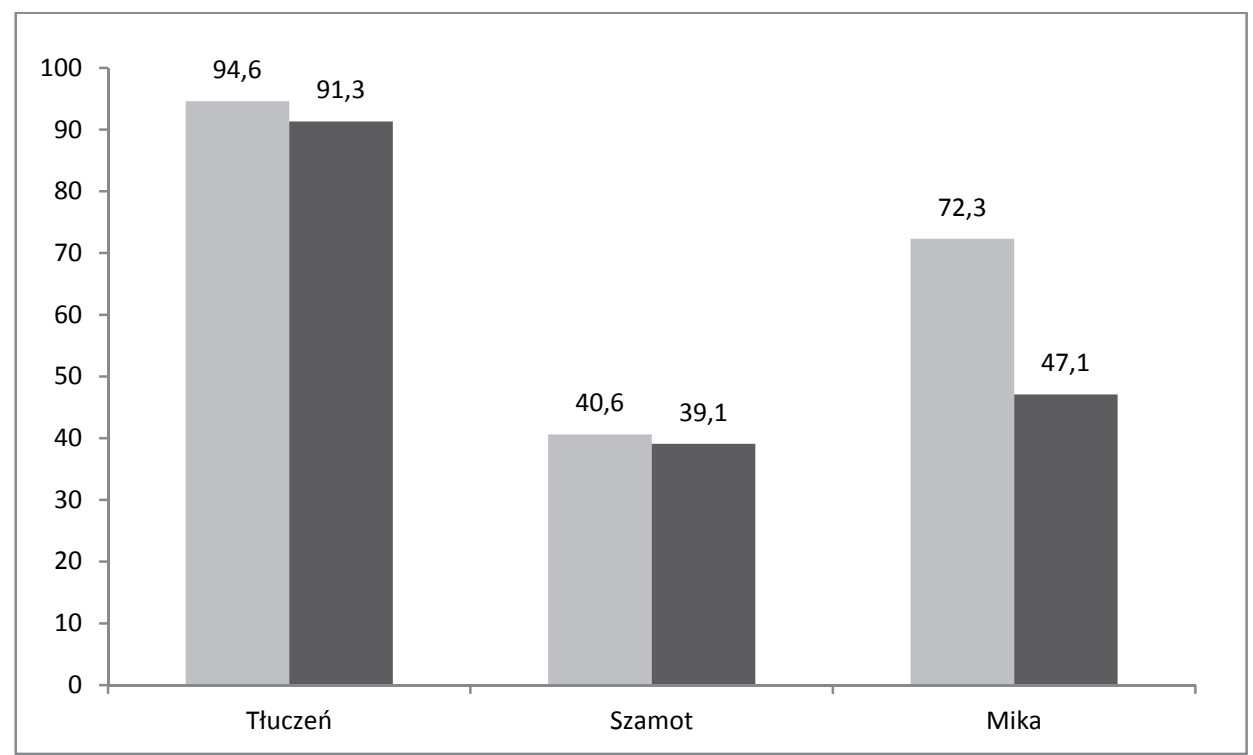

Ryc. 11. Mierzyn stan. 4, obiekt 1 i 2. Dane procentowe występowania domieszki w masie ceramicznej. Wyk. M. Dziewanowski.

Fig. 11. Mierzyn site 4, features 1 and 2. Percentage data on temper in clay body. Prepared by M. Dziewanowski 
Szczegółowy opis znalezisk umożliwił osobne omówienie poszczególnych rodzajów domieszki schudzającej (ryc. 11). Specyficzną cechę receptury, utrudniającą opis znalezisk ceramicznych, stanowi nierównomierne występowanie domieszki, która często tworzyła skupiska kilku frakcji domieszki. Sposób przygotowywania masy ceramicznej spowodował wrażenie czystości ciasta, w którym zalegała domieszka.

Najczęściej występujący i najłatwiejszy w identyfikacji rodzaj domieszki stanowi tłuczeń mineralny (tab. 2). Zbiór charakteryzuje się wyraźną tendencją występowania dużej ilości tłucznia średnio- i gruboziarnistego. W wielu przypadkach stwierdzono okruchy o średnicy 3-6 mm. Zdecydowanie dominuje domieszka tłucznia barwy czerwonej przy udziale różowej, zaś grupa kryształów barwy białej wykazuje większą tendencję zabarwienia w stronę odcieni szarości niż barwy mlecznej.

Tabela 2. Mierzyn stan. 4, obiekt 1 i 2. Zestawienie danych ilościowo-procentowych o zawartości tłucznia mineralnego

Table 2. Mierzyn site 4, features 1 and 2. Summary data on the quantity and percentage of crushed rock content

\begin{tabular}{|l|c|c|c|c|c|c|c|}
\hline \multicolumn{7}{|c|}{ Tłuczeń mineralny } \\
\hline \multicolumn{1}{|c}{ Ilość } & śladowo & mało & średnio & dużo & b. dużo & brak lub? & Suma \\
\hline Liczba & 32 & 63 & 83 & 70 & 11 & 24 & 276 \\
\hline$\%$ & 11,6 & 22,8 & 30 & 25,4 & 4 & 8,7 & 100 \\
\hline Grubość & $<0,5$ & $0,5-1$ & $1-2$ & $2-6$ & & brak lub? & Suma \\
\hline Liczba & 154 & 209 & 176 & 81 & & 15 & 276 \\
\hline$\%$ & 55,8 & 75,7 & 63,8 & 29,3 & & 5,4 & 100 \\
\hline Barwa & czerwona & różowa & biała & czarna & & brak lub? & Suma \\
\hline Liczba & 170 & 74 & 148 & 12 & & 10 & 276 \\
\hline$\%$ & 61,6 & 26,8 & 53,6 & 4,3 & & 3,6 & 100 \\
\hline
\end{tabular}

Tabela 3. Mierzyn stan. 4, obiekt 1 i 2. Zestawienie danych ilościowo-procentowych o zawartości thucznia ceramicznego

Table 3. Mierzyn site 4, features 1 and 2. Summary data on the quantity and percentage of crushed ceramics content

\begin{tabular}{|l|c|c|c|c|c|c|c|}
\hline \multicolumn{1}{|c|}{ Tłuczeń ceramiczny (szamot) } \\
\hline \multicolumn{1}{|c|}{ Ilośś } & śladowo & mało & średnio & dużo & b. dużo & brak lub? & Suma \\
\hline Liczba & 13 & 30 & 27 & 19 & 16 & 168 & 276 \\
\hline$\%$ & 4,7 & 10,9 & 9,8 & 6,9 & 5,8 & 60,9 & 100 \\
\hline Grubość & $<0,5$ & $0,5-1$ & $1-2$ & $2-6$ & & brak & Suma \\
\hline Liczba & 81 & 58 & 28 & 5 & & 164 & 276 \\
\hline$\%$ & 29,3 & 21 & 10,1 & 1,8 & & 59,4 & 100 \\
\hline
\end{tabular}


Najtrudniejszy w identyfikacji rodzaj domieszki stanowi thuczeń ceramiczny, co wynika z bardzo zróżnicowanego zabarwienia masy i ziaren domieszki oraz bardzo często z niewielkich rozmiarów ziaren szamotu (tab. 3). Na skutek procesów podepozycyjnych, które wypłukiwały okruchy szamotu o mniejszej odporności, w wielu przypadkach było możliwe obserwowanie tego komponentu jedynie na powierzchni ścianek.

Najbardziej wyrazistym rodzajem domieszki, identyfikowanym w sztucznym świetle, stanowi grupa łyszczyków (tab. 4). W zbiorze fragmentów, w których zanotowano tę domieszkę, najczęściej występuje duża jej ilość, co stanowi wyrazisty element zabiegów technicznych. Czytelny udział frakcji mikro- i drobnoziarnistej może świadczyć o nieintencjonalnym charakterze domieszki, wynikającym ze stosowania tłucznia granitowego. Wyraźnie dominuje barwa złota, jednak dobrze zaznacza się domieszka barwy czarnej i srebrnej. Kryształy miki pod wpływem wysokiej temperatury pęcznieją i zmieniają kolor na złoty. Znajomość tego procesu pozwala sugerować relatywnie niską temperaturę wypału. O dysproporcji ilościowej w identyfikacji barwy decyduje uwzględnienie w opisie bardzo drobnej, zapewne nieintencjonalnej domieszki miki barwy srebrnej. Kwestia ta wymaga jednak szczegółowej obserwacji pod mikroskopem. Stwierdzone zróżnicowanie grubości mikrokryształów miki może świadczyć o oczyszczaniu surowca przez wykorzystanie zjawiska grawitacji.

Tabela 4. Mierzyn stan. 4, obiekt 1 i 2. Zestawienie danych ilościowo-procentowych o zawartości domieszki miki

Table 4. Mierzyn site 4, features 1 and 2. Summary data on the quantity and percentage of mica inclusion content

\begin{tabular}{|l|c|c|c|c|c|c|c|}
\hline \multicolumn{7}{|c|}{ Grupa łyszczyków (mika, muskowit, biotyt) } \\
\hline \multicolumn{1}{|c}{ Ilość } & śladowo & mało & średnio & dużo & b. dużo & brak lub? & Suma \\
\hline Liczba & 33 & 44 & 33 & 59 & 28 & 76 & 276 \\
\hline$\%$ & 12 & 15,9 & 12 & 21,4 & 10,1 & 27,5 & 100 \\
\hline Grubość & $0,05-0,3$ & $0,3-0,5$ & $0,5-1$ & $1-2$ & $2-6$ & brak lub? & Suma \\
\hline Liczba & 145 & 125 & 62 & 40 & 3 & 86 & 276 \\
\hline$\%$ & 52,5 & 45,3 & 22,5 & 14,5 & 1 & 31,1 & 100 \\
\hline Barwa & złota & srebrna & czarna & & & brak lub? & Suma \\
\hline Liczba & 88 & 31 & 33 & & & 146 & 276 \\
\hline$\%$ & 31,9 & 11,2 & 12 & & & 52,9 & 100 \\
\hline
\end{tabular}

\section{Receptury produkcyjne}

Zakres wariantów receptur obserwowany $\mathrm{w}$ omawianym zbiorze ceramiki jest relatywnie szeroki, $\mathrm{z}$ dominującą recepturą tłuczniową, w tym również współwystępującą $\mathrm{z}$ domieszką szamotową oraz zauważalną czystą recepturą szamotową. 
W kolekcji obecne są również okazy reprezentujące recepturę bezdomieszkową, zawierające bardzo dużą ilość mikroskopijnych kryształów miki (tab. 4, ryc. 11).

Technologia szamotowa (grupa technologiczna I) charakteryzuje się domieszką drobnego, bardzo licznego thucznia szamotowego dodanego do thustej gliny (tab. 3, ryc. 11). Niektóre fragmenty mają strukturę woskową. W tej grupie występują również okazy ze śladowymi ilościami domieszki pylastego tłucznia, nadającego wrażenie szorstkości powierzchni. W zaledwie dziesięciu przypadkach stwierdzono obecność domieszki szamotu, przy braku domieszki miki i małej bądź śladowej ilości thucznia mineralnego. Tylko trzy fragmenty reprezentowały technologię szamotową, charakterystyczną dla zespołów wióreckich grupy wschodniej KPL. Domieszka mineralna występująca w niektórych surowcach plastycznych może być trudna do odróżnienia od szamotu ceramicznego. Na dalszym etapie badań wskazane jest przeprowadzenie specjalistycznych badań w celu zweryfikowania hipotezy o stosowaniu wskazanych surowców glinopodobnych.

Technologia thuczniowa (grupa technologiczna II) charakteryzuje się domieszką średnio- i gruboziarnistego tłucznia skaleniowego barwy czerwonej, różowej i białej, jak również granitowego w różnych konfiguracjach kolorystycznych i metrycznych. Bardzo często tym komponentom towarzyszyła mika różnej wielkości (tab. 2). Uwzględniając znane kolekcje ze strefy zachodniodolnoodrzańskiej należałoby odrębnie traktować następujące cztery warianty tej receptury. Pierwszy wariant receptury thuczniowej z domieszką thucznia kwarcowego barwy białej i skaleniowego barwy mlecznej (grupa IIa) charakteryzuje zespoły późnowstęgowe (Mierzyn, stan. 5 oraz Szczecin-Gumieńce, stan. 17), ale został stwierdzony również w zespołach protoneolitycznych na stanowisku nr 3 w Tanowie (Galiński 1992) oraz w niektórych kolekcjach wczesnopucharowych $\mathrm{w}$ strefie dolnoodrzańskiej. Warianty receptury thuczniowej z domieszką thucznia skaleniowego barwy czerwonej oraz różowej (grupa IIb) można wyróżniać w zależności od ilości i wielkości thucznia. Ten wariant charakteryzuje wszystkie późniejsze zespoły pucharowe i amforowe w strefie dolnoodrzańskiej, ale znany jest również w zespołach protoneolitycznych typu Tanowo. Obserwacją szczególnie istotną dla prowadzonych studiów jest to, że, $\mathrm{w}$ świetle dostępnych źródeł $\mathrm{z}$ terenu Pomorza Zachodniego, różowy i czerwony tłuczeń nie jest znany ze stanowisk późnowstęgowych. Wariant receptury z domieszką thucznia granitowego (grupa IIc) barwy szarawej wraz z innymi rodzajami domieszki mineralnej stwierdza się $\mathrm{w}$ połączeniu z liczną domieszką kryształów miki barwy złotej i czarnej. Wariant receptury z thuczniem mineralnym w postaci łyszczyków (grupa IId) pojawia się często jako naturalna domieszka niektórych surowców plastycznych, jak również w postaci nieintencjonalnego dodatku w recepturach opartych o domieszkę thucznia skaleniowego, kwarcowego i granitowego. Mika funkcjonuje niejednokrotnie jako podstawowa domieszka mineralna, powodująca rozwarstwianie się naczyń ceramicznych. Cechą szczególną omawianej kolekcji jest obecność dużej ilości pyłu barwy srebrnej. Wariant mikowy pojawia się już 
w zespołach późnowstęgowych i dalej występuje w zespołach pucharowych, ale jest najbardziej charakterystyczny dla zespołów kultury hawelańskiej (okres 3200-2800 BC). W zbiorze najlepiej reprezentowana jest technologia mieszana (grupa III) charakteryzująca się współwystępowaniem domieszki tłuczniowej, szamotowej i mikowej, przy zróżnicowanych proporcjach poszczególnych grup wielkościowych.

Ostatnia receptura (grupa nr IV) charakteryzuje się brakiem czytelnej domieszki intencjonalnej. W tej grupie obserwowana jest wyraźna domieszka mikroskopijnego granulatu miki, która występuje w niektórych wychodniach gliny. Sporadycznie zdarzają się fragmenty naczyń wykonanych z gliny thustej.

\section{Techniki produkcyjne}

Podstawę źródłoznawczą dla wydzielania wariantów technik produkcji naczyń ceramicznych stanowią rozważania podejmowane w ramach archeologii doświadczalnej. Prace nad zagadnieniem technologii ceramicznej realizuje przez doświadczalne lepienie naczyń Damian Piłaszewicz, któremu autor zawdzięcza wiele inspiracji w tym aspekcie studiów ceramologicznych ${ }^{4}$. W trakcie obserwacji prowadzonych na niewielkiej kolekcji własnoręcznie wykonanych naczyń ceramicznych oraz przez studia porównawcze podjęto próbę rozszerzenia istniejącej systematyki opisu bazującej na trójdzielnym ewolucyjnym podziale technik (Galiński 1992, s. 88). Obecnie, na podstawie przeprowadzonych studiów, należałoby rozwinąć klasyfikację technik lepienia naczyń w zespołach kultury pucharów lejkowatych.

Grupę techniczną nr I określono jako rozwiniętą technikę U/H, w której nakłada się kolejne prostokątne lub koliste wałki na już istniejącą ściankę. W wyniku dobrego sklejenia i silnego uciskania $w$ trakcie kolejnych faz budowania ścian, układ masy staje się skośny, jednak w poszczególnych miejscach uwidaczniają się nieckowate zawirowania przy ściankach, wskazujące granicę między kolejnymi partiami dokładanego surowca. Wskazany wariant jest łączony z zespołami starszych i środkowych faz kultury pucharów lejkowatych (Dziewanowski, Matuszewska 2011, ryc. 3:4).

Grupę techniczną nr II określono jako wczesny wariant techniki N, w którym kolejne przygotowane elementy są dobrze sklejane ze ścianką. Fragmenty naczyń mają jednolitą strukturę. Dokładna obserwacja przełamów pozwala wskazać miejsca łączenia elementów dokładanych od strony wewnętrznej lub zewnętrznej, a ponadto określić skośny układ masy (Dziewanowski, Matuszewska 2011, ryc. 3:2).

Grupę techniczną nr III określono jako rozwiniętą technikę N, która charakteryzuje się dokładaniem podłużnych taśm, jednak bez wyraźnej standaryzacji kolejnych elementów.

\footnotetext{
${ }^{4}$ Szczególny przykład studiów nad technologią produkcji naczyń ceramicznych stanowi książka Znaki utrwalone w glinie (Mierzwiński 2003), poświęcona ceramice kultury łużyckiej.
} 


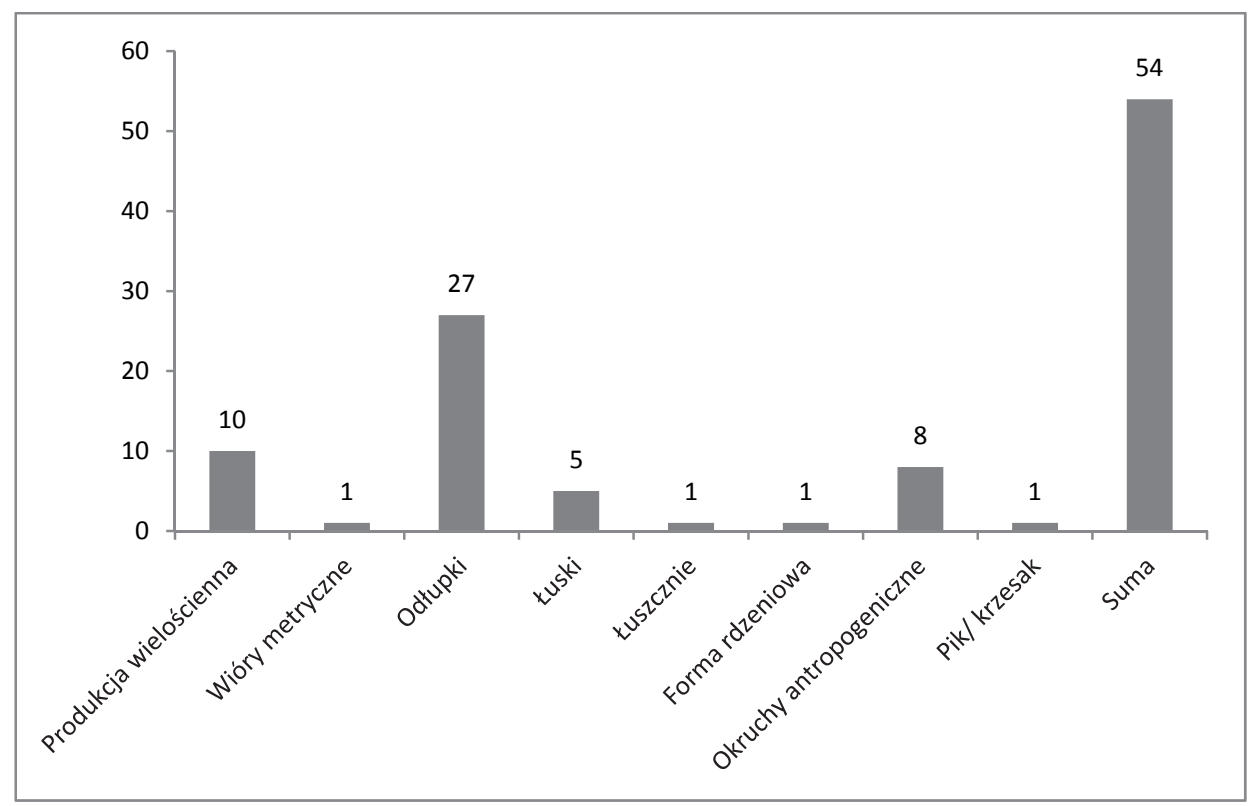

Ryc. 12. Mierzyn stan. 4, obiekt 1 i 2. Struktura ilościowa znalezisk krzemiennych. Wyk. M. Dziewanowski

Fig. 12. Mierzyn site 4, features 1 and 2. Quantitative structure of flint finds. Prepared by M. Dziewanowski

Grupę techniczną nr IV określono jako rozwiniętą technikę N z wykorzystaniem taśm, które są dokładnie przykładane do przygotowanych ścianek. Wariant ten daje w efekcie wyrazistą granicę między elementami konstrukcyjnymi. Fragmenty naczyń wykonanych w tej technice występują w postaci różnej wielkości prostokątów, równoległoboków posiadających w rzucie bocznym przekrój romboidalny. W szczególnych przypadkach krótkie fragmenty mają w rzucie bocznym zarys soczewkowaty. Większe fragmenty naczyń również wykazują równoległe pęknięcia pozwalające identyfikować technikę produkcyjną. Wariant ten jest charakterystyczny dla inwentarzy późnej fazy kultury pucharów lejkowatych, zaś diagnostyczny dla kultury hawelańskiej. Przykład zastosowania takiej techniki w kolekcji z obiektu odkrytego w Mierzynie stanowi misa przedstawiona na rycinie 7:8.

Grupę techniczną nr V określono jako wariant techniki taśmowej polegającej na dokładaniu dużych taśm. W takim przypadku miejsca styków mogą być w różnym stopniu modyfikowane. $\mathrm{W}$ tym wariancie zawiera się również szereg koncepcji bazujących na rozpoczynaniu pracy od dużej bryły gliny, z której wyciągane są ścianki. Taka technika pozostawia ślady w postaci przełamów nieczytelnych, jak również silnie warstwowanych skośnie. W większości sytuacji, gdy cechy techniczne nie są dobrze czytelne, należy uwzględniać stosowanie tej techniki. 


\section{Opis znalezisk krzemiennych}

W skład kolekcji wchodzi 128 znalezisk krzemiennych. Zbiór objęty studiami składa się z 54 wyrobów po wyłączeniu okruchów, drobnych konkrecji i ich fragmentów.

\section{Surowiec krzemienny}

Wszystkie okazy wykonano z lokalnego surowca bałtyckiego, z odmian o matowej powierzchni barwy popielatej oraz odmian o szklistej strukturze barwy herbacianej i czarniawej. Najwięcej okazów wykonano z surowca charakteryzującego się niejednorodną budową z plamami krzemieniaka zróżnicowanej wielkości oraz masą drobnoziarnistą i szklistą barwy od mlecznoszarej i popielatej do ciemnobrunatnej i czarnawej. Surowiec zawiera mikroskopijne plamki barwy mlecznej lub czarnawej oraz żyłki i warstewki. W kilku przypadkach zidentyfikowano odmianę krzemienia barwy szarej lub popielatej o jednolitej, drobnoziarnistej strukturze i matowej powierzchni. K. Siuchniński opisał ten surowiec jako krzemień rugijski (Balcer 1983, s. 48; Siuchniński 1972, s. 87). Na stanowiskach środkowoneolitycznych licznie występują odłupki z produkcji oraz modyfikacji medio- i makrolitycznych siekier czworościennych sporządzonych z tej odmiany krzemienia bałtyckiego.

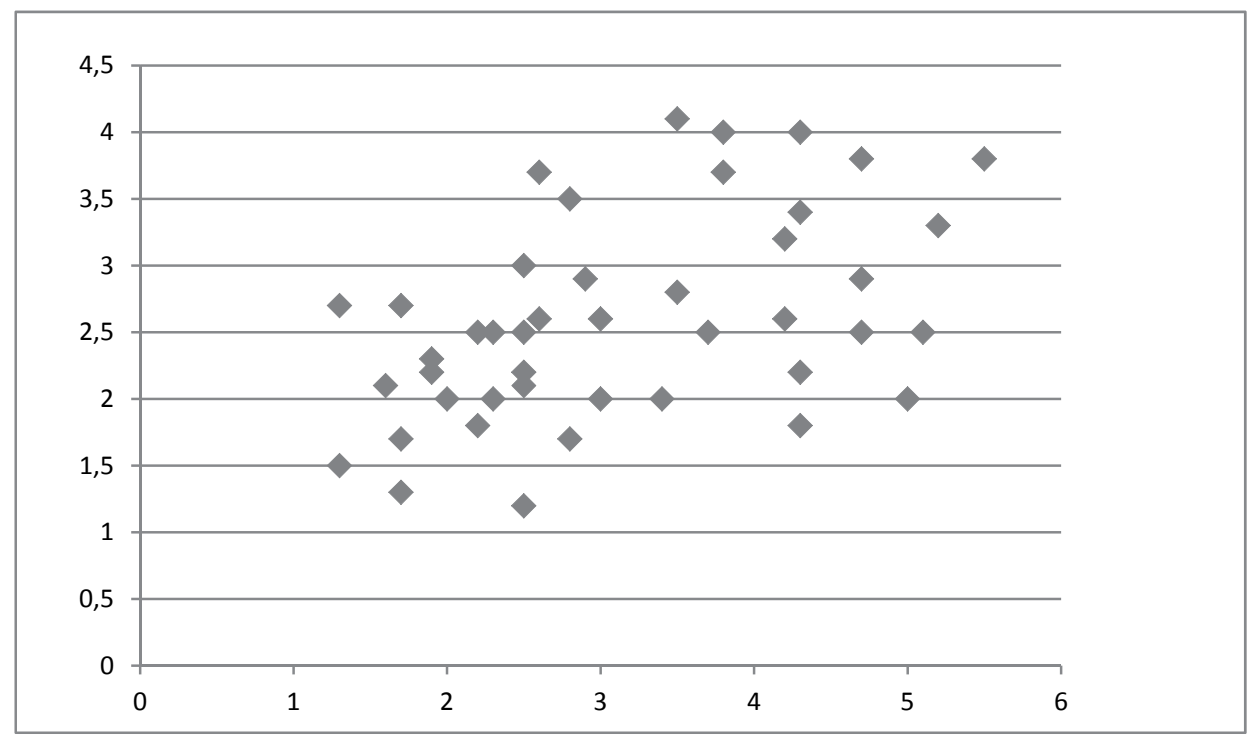

Ryc. 13. Mierzyn stan. 4, obiekt 1 i 2. Parametry metryczne wszystkich znalezisk krzemiennych (cm). Wyk. M. Dziewanowski

Fig. 13. Mierzyn site 4, features 1 and 2. Metric parameters of all flint finds (cm). Prepared by M. Dziewanowski 
Surowcem często używanym jest krzemień mszywiołowy, charakteryzujący się masą mszywiołową barwy białawej, herbacianej oraz brunatnej, z bardzo liczną domieszką skamieniałości. Struktura masy jest bardzo zróżnicowana. Dobrze łupliwe odmiany mają strukturę porcelitową i szklistą, zaś odmiany krzemieniakowe charakteryzują się strukturą gruzełkowatą. W zbiorze zidentyfikowano również po jednym okazie wykonanym $\mathrm{z}$ bałtyckiej odmiany krzemienia pasiastego oraz z surowca krzemieniopodobnego zwanego „rogowcem”.

Zaledwie 12 okazów przekraczało 4 centymetry długości, zaś najdłuższy miał $5,5 \mathrm{~cm}$ (ryc. 13). Na podstawie pozyskanego materiału zabytkowego nie jest możliwe szacowanie wielkości i jakości konkrecji krzemiennych.

\section{Syntetyzujące omówienie znalezisk krzemiennych}

Kolekcja wyrobów krzemiennych pozyskana z zachodniej części jamy mieszkalnej kultury pucharów lejkowatych zawiera pojedyncze, diagnostyczne elementy, wartościowe w studiach nad zagadnieniem środkowoneolitycznej technologii krzemieniarskiej. Szczególny element stanowi znalezisko zbrojnika trapezowatego z odłupka (ryc. 8:2), po raz pierwszy odkrytego w obiekcie kultury pucharów lejkowatych na Pomorzu Zachodnim. Znamiennym jest pozyskanie tego wyrobu z najstarszej stratygraficznie struktury, która dostarczyła również fragmentu naczynia ostrodennego. Duże znaczenie posiada również drapacz z retuszowanymi bokami, który po obróbce termicznej został przetworzony na rylec (ryc. 6:9). Dotychczas nie pozyskano materiałów z Pomorza Zachodniego, które mogą stanowić źródło analogii formalnych dla wymienionych narzędzi.

W inwentarzu wystąił jeden metryczny wiór o jednym korowym boku, a drugim o dwupiętowym układzie negatywów, wykonany ze szklistego surowca barwy czarnawej, który należy wiązać ze wstępnym etapem zaprawy (ryc. 7:7). Obserwowane na zaprawiakach miękkie cechy techniczne w postaci wyraźnych warg, wydatnych, gładkich sęczków i zaprawianych, wielonegatywowych piętek pozwalają dopuszczać związek niektórych zaprawiaków z techniką pośrednika rogowego. W kolekcji zidentyfikowano 10 wyrobów, które mogą być wiązane z produkcją narzędzi wielościennych. Jeden odłupek noszący ślady użytkowania ma zestaw cech piętki, strony negatywowej oraz rzutu bocznego, pozwalający jednoznacznie łączyć wyrób z zaawansowanym etapem formowania grzbietu siekiery czworościennej. W kolekcji zidentyfikowano jeden łuszczeń dwubiegunowy. $Z$ techniką łuszczniową łączona jest również nieregularna forma rdzeniowa o średnicy około 2,7 cm wykonana z krzemienia charakteryzującego się brązowawą masą mszywiołową. Okaz posiada ślady rozbijania na podkładce oraz modyfikacji przypominającej retusz lub produkcję wiórkową. W grupie odłupków o twardych cechach technicznych stwierdzono dwa okazy, które mogą być uznane za świadectwo realizacji metod odłupkowych. 
Brak $\mathrm{w}$ zbiorze świadectw produkcji wiórowej oraz zarejestrowanie pojedynczych wyrobów związanych z produkcją narzędzi wielościennych jest zastanawiające $\mathrm{z}$ uwagi na masowe występowanie znalezisk krzemiennych na powierzchni stanowiska $\mathrm{i} w$ warstwach akumulacyjnokulturowych $\mathrm{w}$ postaci odpadów produkcyjnych, fragmentów siekier i wiórów (ryc. 12).

\section{Analizy traseologiczne}

Bazując na szczegółowych studiach makroskopowych, wydzielono okazy wymagające ekspertyzy traseologicznej. Studia te objęły 11 wyrobów krzemiennych zróżnicowanych między sobą pod względem morfologicznym, jak i stanu zachowania na poziomie makroskopowym (ryc. 14). W celu szczegółowego określenia charakteru śladów powstałych na powierzchniach krzemiennych użyto mikroskopu metalograficznego Nikon LV150 o powiększeniach rzędu 50×, 100× oraz 200×, umożliwiającymi szczegółową identyfikację poszczególnych śladów - wykruszeń, rys i wyświeceń.

Zaledwie pięć okazów ujawniło ślady użytkowania, a na piętce jednego wyrobu stwierdzono ślady związane z procesem produkcyjnym. Wyróżniono trzy wytwory służące do cięcia zboża (ryc. 15:1,2; 17:4), jeden związany najprawdopodobniej

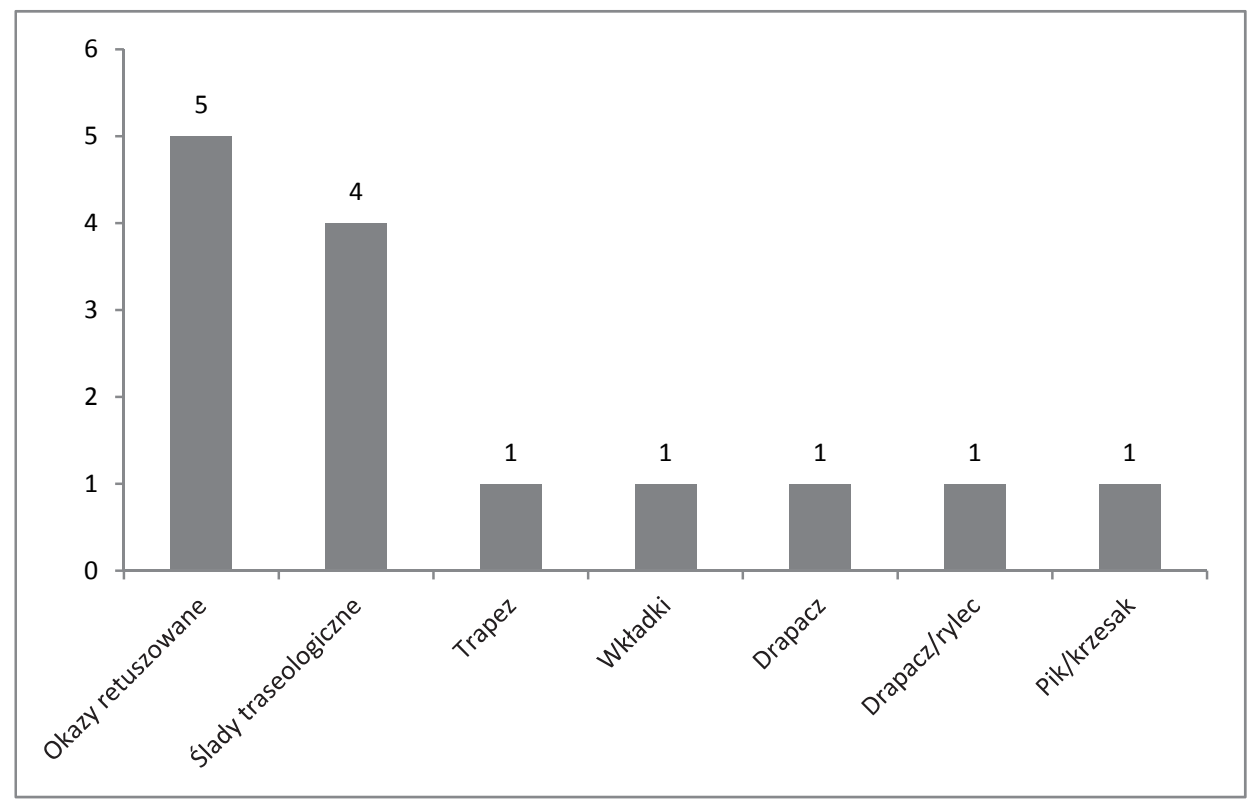

Ryc. 14. Mierzyn stan. 4, obiekt 1 i 2. Struktura liczbowa narzędzi krzemiennych. Wyk. M. Dziewanowski Fig. 14. Mierzyn site 4, features 1 and 2. Quantitative structure of flint tools. Prepared by M. Dziewanowski 

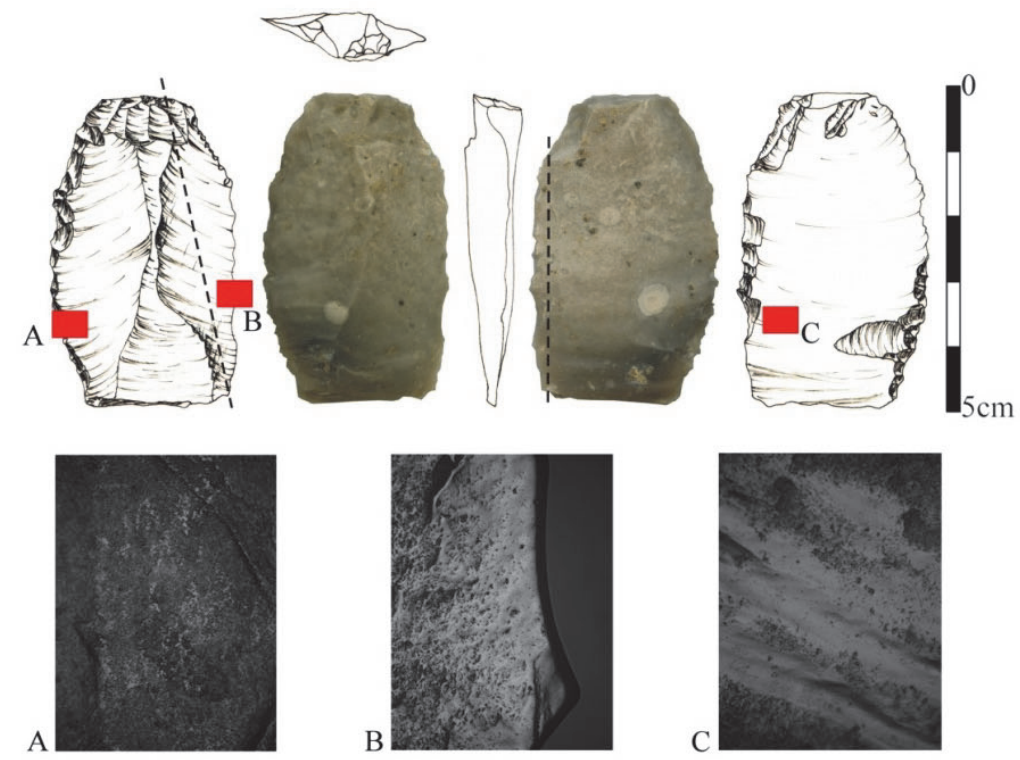

1
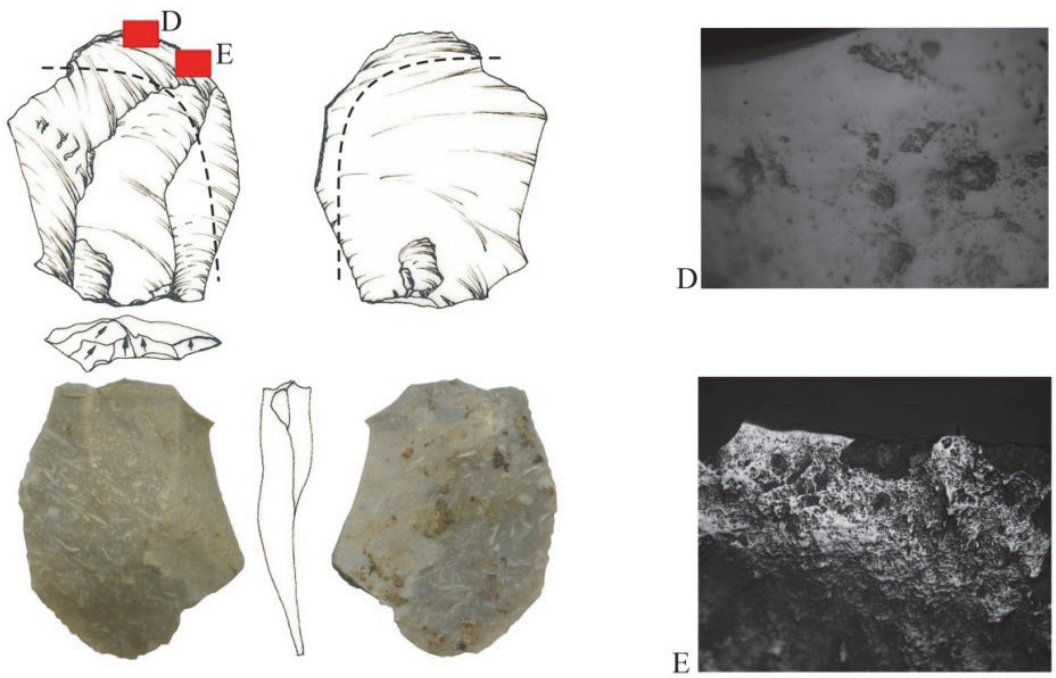

2

Ryc. 15. Mierzyn, stan. 4. Narzędzia retuszowane ze śladami użytkowania. Zbiory Muzeum Narodowego w Szczecinie. B, D, E - ślady cięcia roślin krzemionkowych; A, C - ślady oprawy (powiększenia: A, C-100×; B, E-50×; D - 200×). Wyk. M. Dziewanowski i K. Pyżewicz

Fig. 15. Mierzyn, site 4. Retouched implements showing use-wear. Collection of the National Museum in Szczecin. B, D, E - traces of cutting silica plants; A, C - traces of hafting (magnification: A, C - 100×; B, E-50×; D - 200×). Prepared by M. Dziewanowski and K. Pyżewicz 
z obróbką skóry (ryc. 17:1) oraz jeden krzesak (ryc. 17:2), co nawiązuje do ogólnej wiedzy na temat użytkowania narzędzi krzemiennych przez ugrupowania kultury pucharów lejkowatych Niżu Polskiego (por. m.in. Małecka-Kukawka 2001, s. 103-125; Osipowicz 2010, s. 160 i n.; Osypiński, Pyżewicz 2015; Pyżewicz 2015; Winiarska-Kabacińska 2004).

Pierwszy z użytkowanych wytworów - wiórowiec (ryc. 15:1) odznacza się wyraźnymi, mocno rozwiniętymi śladami funkcjonalnymi oraz zastosowania oprawy, które nie uległy zniekształceniom podczas działalności czynników podepozycyjnych. Wzdłuż jednej z dłuższych krawędzi bocznych zaobserwowano rozwinięte wyświecenia, zlokalizowane zarówno na stronie negatywowej (gdzie zachodzi daleko na wewnętrzne partie narzędzi), jak i pozytywowej wytworu (wówczas zlokalizowane jest w strefie przykrawędne). Wybłyszczenia, o szerokości przeważnie kilku milimetrów, rozciągają się głównie na powierzchni niepokrytej retuszem, między negatywami łusek. W ramach powierzchni wyświeconej odnotowane zostały liczne ślady liniowe, umiejscowione równolegle do krawędzi bocznej. Zaprezentowane mikrooznaki są dystynktywne dla tzw. wkładek żniwnych. Dodatkowo miejscowy, nieco odmienny charakter wyświecenia może wskazywać, że narzędzie służyło do cięcia też innych roślin krzemionkowych. Wyraźna granica występowania śladów użytkowych wskazuje jednocześnie potencjalną linię przebiegu zakończenia oprawy. O jej zastosowaniu świadczą intensywne starcia wypukłych partii krzemiennych, przede wszystkim grani międzynegatywowych - w miejscach narażonych na najsilniejsze oddziaływanie osady. Na powierzchni dwóch odłupów odnotowano ślady, których morfologia wskazuje na kontakt narzędzia z roślinami zielnymi. Charakter mikroskopowych deformacji użytkowych jest analogiczny do śladów opisanych wyżej. Dlatego też z dużym prawdopodobieństwem można uznać dany okaz za narzędzie do cięcia roślin krzemionkowych. Intensywne ślady liniowe, ułożone w równolegle względem krawędzi bocznej, dowodzą, że podczas pracy wykonywano ruchy wzdłużne względem osi symetrii narzędzia. Na podstawie lokalizacji znamion użytkowych i granicy ich występowania można podjąc się próby ukazania sposobu oprawy danego okazu: najpewniej artefakty tkwiły głęboko w osadzie, a wystawała jedynie część dystalna oraz część bocznej krawędzi.

Kolejny z przeanalizowanych artefaktów odznacza się mniej dystynktywnymi śladami niż w przypadkach opisanych wyżej (ryc. 15:2). Wzdłuż dwóch krawędzi bocznej i dolnej, zidentyfikowane deformacje można powiązać z użytkowaniem i być może zastosowaniem jakiegoś typu oprawy. Na podstawie ich morfologii można pokusić się o interpretację, że przy użyciu danego odłupka wykonywano czynności związane z obróbką substancji organicznej - najpewniej skóry. Ponadto część z mikrooznak nieco przypomina te wynikające z kontaktu z drewnem. Dlatego też nie należy wykluczać dwufunkcyjności tego narzędzia. Lokalizacja śladów najintensywniejsze występują na styku dolnej z boczną krawędzią, na „cyplowatym” fragmencie - może być wynikiem zastosowania danego okazu jako narzędzia służącego do przekłuwania czy żłobienia surowca organicznego. 

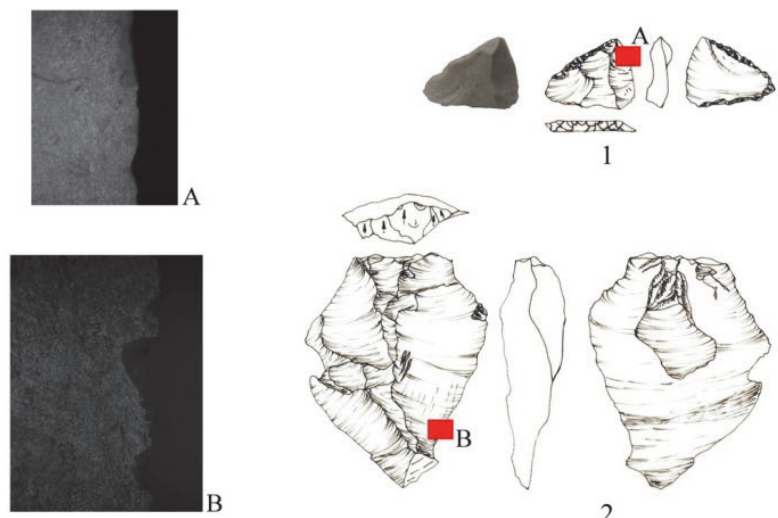

1
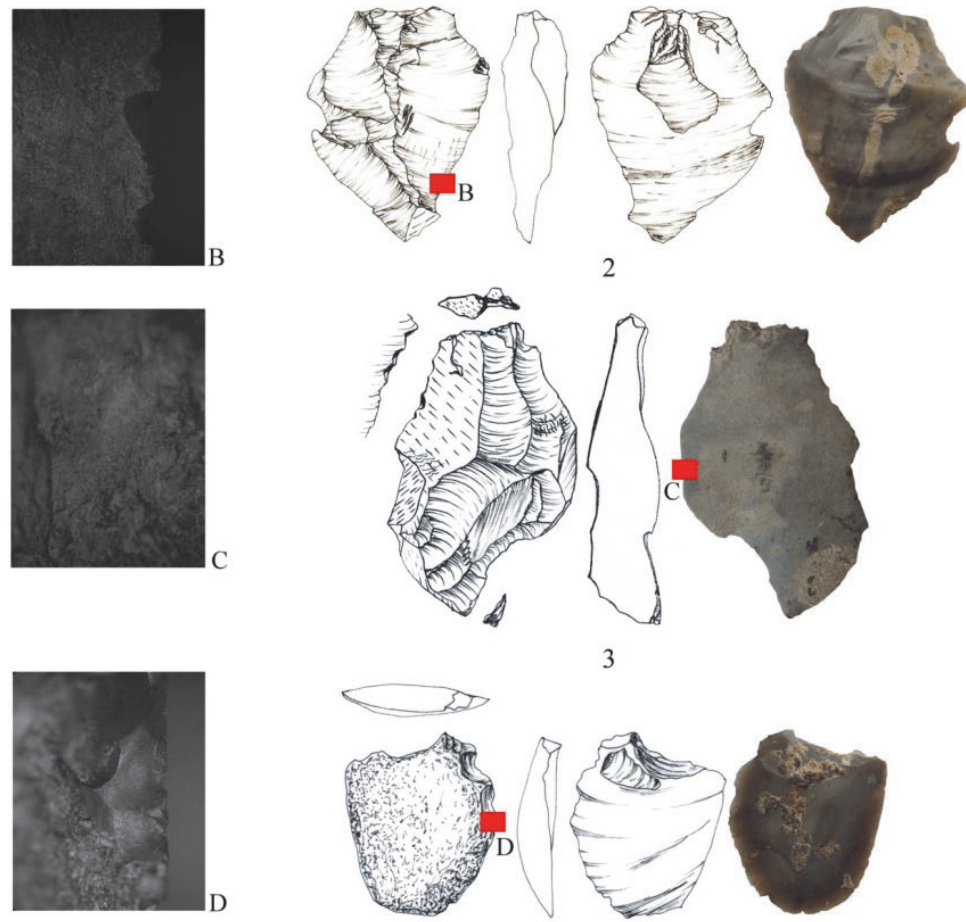

2

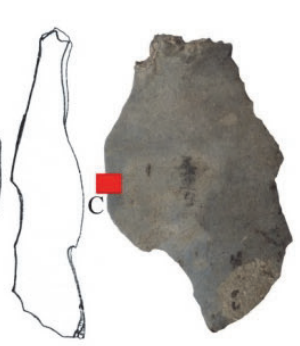

3
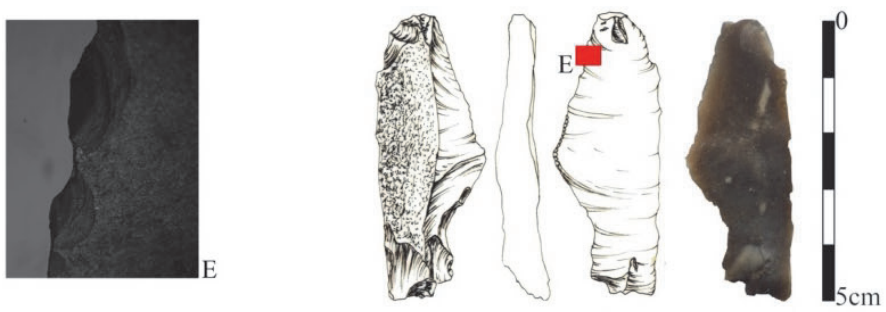

5

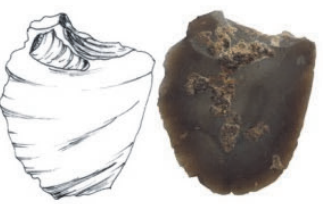

4

Ryc. 16. Mierzyn, stan. 4. Narzędzia retuszowane ze śladami użytkowania i podepozycyjnymi. Zbiory Muzeum Narodowego w Szczecinie. A - ślady obróbki skóry; B - ślady krzesania (?); C - ślady podepozycyjne; D - ślady cięcia roślin krzemionkowych (powiększenia: A - 200×; B-C - 100×; D - 50×). Wyk. M. Dziewanowski i K. Pyżewicz

Fig. 16. Mierzyn, site 4. Retouched implements with use-wear and postdepositional traces. Collection of the National Museum in Szczecin. A - traces of hide processing; B - traces of striking (?); C - postdepositional traces; D - traces of cutting silica plants (magnification: A $-200 \times$; B-C $-100 \times$; D $-50 \times$ ). 

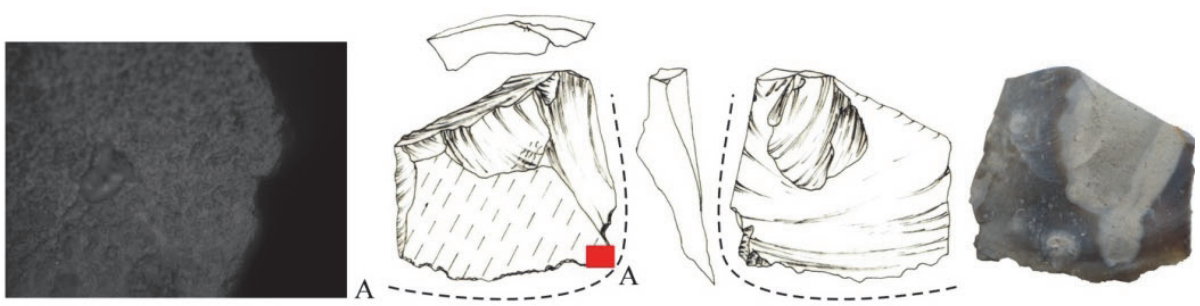

1
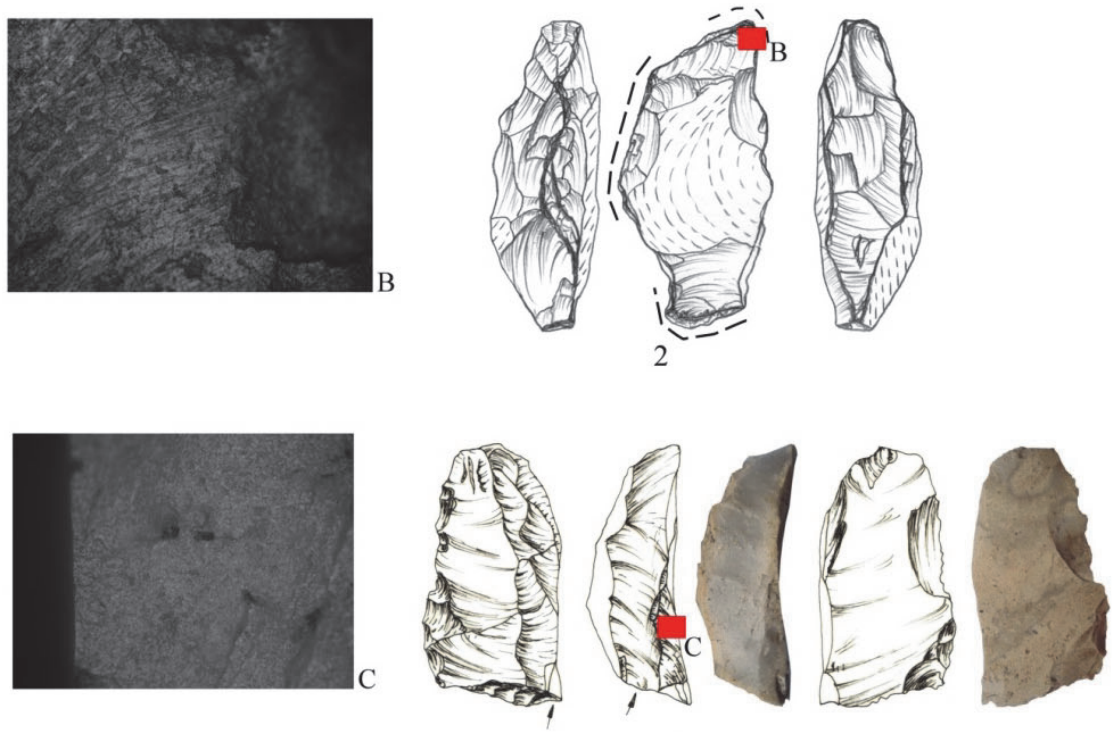

3
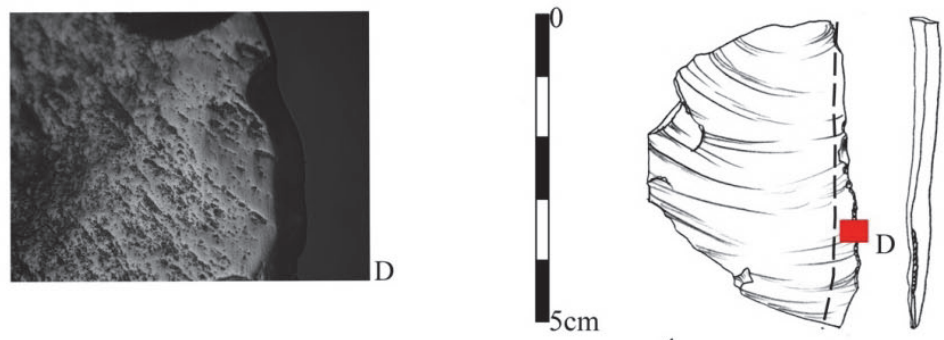

4

Ryc. 17. Mierzyn, stan. 4. Wyroby retuszowane oraz z mikrowykruszeniami bez mikroskopowych śladów użytkowania. Zbiory Muzeum Narodowego w Szczecinie. A-E - ślady podepozycyjne (powiększenia: A - 100×; B, D-E - 50×; C - 200×). Wyk. M. Dziewanowski i K. Pyżewicz

Fig. 17. Mierzyn, site 4. Retouched implements, with micro-chipping, showing no microscopic use-wear. Collection of the National Museum in Szczecin. A-E - postdepositional traces (magnification: A - 100×; B, D-E - 50×; C-200×). Prepared by M. Dziewanowski and K. Pyżewicz 
Jeden z wytworów mógł spełniać rolę krzesaka (ryc. 17:2), o czym świadczą odnotowane zgrupowania śladów liniowych na wierzchołku (por. m.in. Pyżewicz, Rozbiegalski 2012). Należy jednak zauważyć, że charakter wyświeceń nie jest dystynktywny.

Pozostałe okazy nie charakteryzują się śladami, które wskazywałyby na kontekst użytkowy (ryc. 16:1-5). Nie można z pewnością wykluczyć, że artefakty te nie zostały w jakiś sposób wykorzystane w okresie neolitu. Być może znamiona funkcjonalne zostały zamazane przez działalność czynników podepozycyjnych - mechanicznych i naturalnych, czego efektem jest m.in. patyna odnotowana na powierzchni części z przebadanych okazów z Mierzyna. Ponadto należy zauważyć, że niektóre czynności, szczególnie te o krótkotrwałym charakterze, jak np. wykorzystanie form krzemiennych jako elementów broni miotanej, nie pozostawiają ewidentnych śladów możliwych do identyfikacji przez zastosowanie analizy mikroskopowej.

\section{Opis znalezisk kamiennych}

W trakcie odsłaniania stropu obiektu znaleziono również trzy wyroby kamienne:

1. Ostrokrawędzista płytka $\mathrm{z}$ ciemnopomarańczowego średnioziarnistego piaskowca o zarysie wielobocznym i wymiarach około $15 \times 10 \mathrm{~cm}$ nosi ślady użytkowania w postaci wąskiego pasa zagładzeń.

2. Nieregularnie owalny otoczak twardego kwarcytu barwy jasnobrązowej, o średnicy około $6 \mathrm{~cm}$, nosi ślady użytkowania w postaci kilkunastu wykruszeń ulokowanych na odcinku $4 \mathrm{~cm}$.

3. Rozcieracz o zarysie nieregularnie kolistym i średnicy $10 \mathrm{~cm}$ wykonany z twardego średnioziarnistego piaskowca barwy czerwonawo-brązowawej.

\section{CHRONOLOGIA ZABYTKÓW POZYSKANYCH NA STANOWISKU NR 4 W MIERZYNIE}

Sporządzenie szczegółowej bazy danych i zestawieniu cech jakościowoilościowych ceramiki i wytworów krzemiennych umożliwiło scharakteryzowanie specyfiki technologiczno-stylistycznej diagnostycznej dla rozważań chronologicznych. Nieliczne fragmenty z partii załomowych i przybrzeżnych ukazały wyjątkową oszczędność w zakresie zdobnictwa. Cechę receptur technologicznych rozpoznanych w kolekcji stanowi wyrazista dominacja domieszki średnio i gruboziarnistego thucznia mineralnego oraz stosowanie drobnej i bardzo drobnej domieszki thucznia ceramicznego.

Dla studiów kulturowo-historycznych kluczowe znaczenie ma zawartość zasypiska piwniczki, w którym znaleziono fragment naczynia ostrodennego, fragment 
szyjki pucharka, fragment dużej amfory oraz zbrojnik trapezowaty. Fragment szyjki pucharka o znacznym kącie nachylenia, zaopatrzonego na przejściu szyjki w brzusiec w poziomy guzek, wykazuje zbieżności stylistyczne z naczyniami ostrodennymi typu Pasewalk, które są umieszczane przez różnych badaczy w przedziale czasowym 3700-3500 BC (Kirsch 1994; Kośko 1982, s. 165; Mende 2001, s. 37; Menke 1988, s. 51; Szmyt 1996, s. 266; Siuchniński 1972, s. 82; dalsze dane Wotzka 1998, s. 93). Na stanowisku w Warlinie odkryto w warstwie kulturowej fragmenty naczyń o zakolonych dnach, silnie pochylonych szyjkach oraz charakterystycznych zdobieniach złożonych z poziomych guzków plastycznych (Mende 2001, s. 37). Najbliższe analogie dla tych form dostarczają znaleziska pucharków ostrodennych z Pasewalku i Wartina.

Wykorzystanie techniki dopasowywania fragmentów zaowocowało składankami i umożliwiło pogrupowanie zbioru na naczynia ceramiczne. Obserwacja rozprzestrzenienia znalezisk pozwala wskazać względnie krótkotrwały czas funkcjonowania założenia lub przemieszczanie osadów próchnicznych w trakcie kolejnych faz wykorzystywania zagłębienia. W zasypisku jamy mieszkalnej stwierdzono współwystępowanie ceramiki pozbawionej ornamentyki, którą można łączyć z początkiem IV tysiąclecia BC i ceramiki głęboko nakłuwanej wiązanej z drugą i trzecią ćwiercią IV tysiąclecia BC. Znaleziska tego typu można uznać za jednoczasowe, jak również badać oddzielnie (Kabaciński, Sobkowiak-Tabaka 2004, s. 31-37, ryc. 54). Wskazane współwystępowanie różnych stylistyk może stanowić świadectwo złożoności kultury ugrupowań miejscowych, ale również ukazywać proces krystalizowania się nowych systemów na bazie struktur lokalnych ewoluujących pod wpływem kontaktów interregionalnych, między innymi ze społecznościami zamieszkującymi obszar środkowych i północnych Niemiec. Na podstawie przeprowadzonych studiów porównawczych pozyskane materiały kultury pucharów lejkowatych z Mierzyna można wstępnie umieścić w okresie 3700-3400 BC, w ramach cech stylistyk ceramicznych kultury baalberskiej i kultury michelsberskiej (Baldia, Frink, Boulanger 2008, s. 26), a także grupy wschodniej kultury pucharów lejkowatych i kultury amfor kulistych.

W świetle najnowszego odkrycia znaleziska naczyń ostrodennych ze stanowiska $\mathrm{nr} 4 \mathrm{w}$ Mierzynie stanowią reprezentację różnych stadiów transformacji systemu postmezolitycznego i postwstęgowego pod wpływem oddziaływań nowych systemów kulturowych, reprezentowanych przez kulturę michelsberską (Rzepecki 2004, s. 152-160).

\section{PODSUMOWANIE}

Badania sondażowe przeprowadzone w 2004 r. dostarczyły kolejny fragment naczynia ostrodennego ze stanowiska $\mathrm{nr} 4 \mathrm{w}$ Mierzynie. Dla niniejszego opracowania sporządzono szczegółowy opis i dokumentację rysunkową znalezisk, a także 
wykonano ekspertyzę traseologiczną wybranych znalezisk krzemiennych. Równocześnie opracowano dokumentację polową i rozważono możliwe interpretacje powstawania wypełniska obiektu. Pozyskana kolekcja ceramiki oraz wyrobów krzemiennych umożliwiły podjęcie studiów nad zagadnieniem zespołów z pierwszej połowy IV tysiąclecia $\mathrm{BC}$, zawierających $\mathrm{w}$ inwentarzu naczynia ostrodenne. W rezultacie dokonanych odkryć należy ponownie sformułować pytanie o obecność społeczności postmezolitycznych na terenie Wału Stobniańskiego i możliwość identyfikowania tych zjawisk w kulturze materialnej. Wyniki tych rozważań będą miały znaczenie dla studiów nad zagadnieniem idei naczyń ze stożkowatym dnem w kulturze społeczności nadbałtyckiej. Wyniki studiów traseologicznych - zidentyfikowana niewielka liczba narzędzi oraz obecność okazów związanych z długotrwałą i intensywną obróbką miękkich surowców organicznych (roślinnych) potwierdzają wstępną sugestię o mieszkalnym charakterze obiektu.

Wskazane byłoby uzyskanie pełniejszych danych z terenu Wału Stobniańskiego, umożliwiających prześledzenie historii społeczności użytkujących naczynia ostrodenne w IV tysiącleciu BC w strefie wschodniomeklemburskiej. Niestety kluczowe egzemplarze omawianych pucharków z Pasewalku, Rossow i Wartina nie mają pełniejszego kontekstu i ich datowanie nastręcza dużych trudności. Posiadamy jedynie dane pośrednie określające znaczenie ugrupowań protoneolitycznych $\mathrm{w}$ genezie zjawiska pucharków ostrodennych typu Pasewalk. Na obecnym etapie studiów okazy te można ogólnie łączyć z oddziaływaniami kultury michelsberskiej oraz baalberskiej.

Niestety brak liczniejszych kolekcji oraz datowań bezwzględnych utrudnia pełne scharakteryzowanie osadnictwa kultury pucharów lejkowatych (Jankowska 1983, 1996, 2009) reprezentowanego przez obiekt odkryty na stanowisku nr 4 w Mierzynie. Fragmentaryczne przebadanie jamy gospodarczej w 2004 r. pozwala mieć nadzieję na uzupełnienie w przyszłości cennego inwentarza. Ten postulat wynika nie tylko z potrzeb naukowo-badawczych, ale również prowadzonych prac ziemnych o charakterze inwestycyjnym, niszczących bezpowrotnie stanowiska archeologiczne, a w nikłym procencie objętych archeologicznymi pracami dokumentacyjnymi (Dziewanowski 2013). Budowy osiedli na terenie obiektów archeologicznych bez nadzorów archeologicznych dokumentują również badania interwencyjne na stanowisku nr 9, przeprowadzone w 2010 r. w ramach współpracy między Muzeum Narodowym w Szczecinie i Uniwersytetem Szczecińskim. W ich wyniku odkryto kolejny obiekt kultury pucharów lejkowatych z naczyniem ostrodennym. Materiały te, kluczowe dla dalszych studiów nad kontekstem kulturowo-historycznym tworzenia się nowych jakości technologicznych, mają być przedmiotem odrębnego opracowania (Dziewanowski, Matuszewska 2011).

Stanowiska neolityczne z Mierzyna reprezentują najbogatsze w znaleziska krzemienne, rozpoznane miejsca obróbki krzemienia w kulturze pucharów lejkowatych i kulturze amfor kulistych na terenie Pomorza Zachodniego (Dziewanowski 2015). Intensywne wykorzystywanie surowców krzemionkowych na potrzeby pro- 
dukcji siekier i wiórów nastąpiło w pierwszej połowie IV tysiąclecia, jednak dokładny przebieg rozwoju gospodarki krzemieniarskiej nadal wymaga szczegółowych badań (Dziewanowski 2012a, 2012b, 2013, 2014; Dziewanowski, Szemelak 2016). Zespoły typu Mierzyn 4 stanowią istotny ślad w poznaniu początków produkcji siekier czworościennych oraz rozwoju technologii krzemieniarskiej na terenie strefy dolnoodrzańskiej.

\section{BIBLIOGRAFIA}

Balcer B.

1983a Wytwórczość narzędzi krzemiennych w neolicie ziem Polski. Wrocław - Warszawa Kraków - Gdańsk - Łódź: Zakład Narodowy im. Ossolińskich, Wydawnictwo Polskiej Akademii Nauk.

Balcer B.

1983b Z badań nad rozwojem krzemieniarstwa neolitycznego na Pomorzu. W: T. Malinowski (red.), Problemy epoki kamienia na Pomorzu (s. 203-216). Słupsk: Wyższa Szkoła Pedagogiczna w Słupsku, Muzeum Pomorza Środkowego w Słupsku.

Baldia O.M., Frink S.D., Boulanger T.M.

2008 Problems in the Archeological Legacy: The TRB/Lengyel-Baden Conundrum. W: M. Furholt, M. Szmyt, A. Zastawny (red.), The Baden Complex and the Outside World. Proceedings of the 12th Annual Meeting of the EAA in Cracow 19-24th September 2006 (Studia nad Pradziejami Europy Środkowej, 4, s. 25-49). Bonn: In Kommission bei Dr. Rudolf Habelt GmbH.

Borówka R. i in. (red.)

2002 Przyroda Pomorza Zachodniego. Szczecin: Oficyna in Plus.

Czarnecki M.

1981 Mesolithic in Szczecin Lowland, Mesolithikum in Europe. Veröffenlichungen des Museums für Ur und-Frügeschichte in Potsdam, 14/15, s. 345-354.

Czarnecki M.

1983 Początki zasiedlenia w paleolicie i mezolicie. W: W. Filipowiak, G. Labuda (red.),

Dzieje Szczecina, t. 1, Pradzieje Szczecina (s. 59-101). Warszawa - Poznań: Państwowe Wydawnictwo Naukowe.

Cyrek K., Grygiel R., Nowak K.

1983 Podstawy wydzielenia mezolitu ceramicznego na Niżu Polskim. W: T. Malinowski (red.), Problemy epoki kamienia na Pomorzu (s. 85-110). Słupsk: Wyższa Szkoła Peda-

Dziewanowski M. gogiczna w Słupsku, Muzeum Pomorza Środkowego w Słupsku.

2005 Sprawozdanie z interwencyjnych prac wykopaliskowych na stanowisku $\mathrm{nr} 4 \mathrm{w}$ Mierzynie.

Dziewanowski M.

[Maszynopis w archiwum Wojewódzkiego Konserwatora Zabytków w Szczecinie].

2008 Kompleks pracowniano-osadniczy z epoki kamienia i wczesnej epoki brazu w Mierzynie (rezultaty odkryć dokonanych na stan. 4 i 7 w Mierzynie w latach 2005-2008). [Maszynopis w archiwum Wojewódzkiego Konserwatora Zabytków w Szczecinie].

Dziewanowski M.

2012a Stan badań nad przemysłami środkowo-późnoneolitycznymi na Pomorzu Zachodnim. Acta Universitatis Lodziensis Folia Archeologica, 28, s. 25-57. 
Dziewanowski M.

2012b Najnowsze odkrycia z epoki kamienia na stanowisku nr 3 w Chwarstnicy, woj. zachodniopomorskie. Materiały Zachodniopomorskie, rocznik 2012, VIII(1), (Archeologia), s. 279-287.

Dziewanowski M.

2013 Wyniki badań interwencyjnych na wielokulturowym stanowisku nr 5 (AZP 30-04/106) w Mierzynie, gm. Dobra Szczecińska. W: E. Fudzińska (red.), XVIII Sesja Pomorzoznawcza, t. 1, Od epoki kamienia do okresu rzymskiego (s. 11-29). Malbork: Muzeum Zamkowe.

Dziewanowski M.

2014 Stan badań nad produkcją narzędzi wielościennych w okresie funkcjonowania kultury pucharów lejkowatych na Pomorzu Zachodnim. Fontes Archaeologici Posnanienses, 50(2), s. 163-183.

Dziewanowski M.

2015 Podsumowanie badań zrealizowanych na terenie Gminy Kołbaskowo w latach 2011-2013. Przyczynek do studiów mikroregionalnych Wzniesień Szczecinskich. W: A. Janowski, K. Kowalski, B. Rogalski, S. Słowiński, P. Wojdak (red.), XIX Sesja Pomorzoznawcza, t. 1, Od epoki kamienia do okresu rzymskiego (s. 11-30). Szczecin: Muzeum Narodowe.

Dziewanowski M., Matuszewska A.

2011 Mierzyn, gm. Dobra Szczecińska, stanowisko archeologiczne nr 9 (AZP 30-04/83). Wstępna prezentacja wyników badań archeologicznych zrealizowanych $w$ ramach wspótpracy między Muzeum Narodowym w Szczecinie i Uniwersytetem Szczecińskim pod kierunkiem dr Agnieszki Matuszewskiej (05 lipca - 31 sierpnia 2010). [Maszynopis w archiwum Wojewódzkiego Konserwatora Zabytków w Szczecinie].

Dziewanowski M, Szemelak R.

2016 Wstępne wyniki badań tywiańskiego mikroregionu produkcyjnego. W: W. Borkowski, B. Sałacińska, S. Sałaciński (red.), Krzemień narzutowy w pradziejach. Materiały z konferencji w „Mądralinie” w Otwocku, 18-20 października 2010 (Studia nad Gospodarka Surowcami Krzemiennymi w Pradziejach, 8, s. 363-381). Warszawa: Państwowe Muzeum Archeologiczne.

Fock G.

1941 Tulpenbecher und Kragenflasche aus einem jungsteinzeitlichen Grab von Racibórz Süd. Nachtrichtenblatt für deutsche Vorzeit, 17, s. 37-39.

Galiński T.

1987 Zespoły typu Tanowo. Zachodniopomorski ekwiwalent ugrupowania Ertebølle-Ellerbek-Lietzow. Materiały Zachodniopomorskie, 33, s. 7-49.

Galiński T.

1991 Mezolit ceramiczny i neolit strefy leśnej. Archeologia Polski, 36(1-2), s. 5-52.

Galiński T.

1992 Obozowisko mezolityczne i protoneolityczne na stanowisku w Tanowie badane w latach 1989-1991. Materiaty Zachodniopomorskie, 38, s. 53-123.

Galiński T.

1997 Materiały do mapy osadnictwa w epoce kamienia na Pomorzu Zachodnim. Materiaty Zachodniopomorskie, 43, s. 7-99.

Galiński T.

2005 Nowe materiały tzw. fazy wczesnopucharowej osadnictwa protoneolitycznego na Pomorzu. Folia Praehistorica Posnaniensia, 12, s. 71-91.

Gadawski A.

1958 Zagadnienie kultury „ceramiki grzebykowej” w Polsce, Wiadomości Archeologiczne 25(4), s. 287-314. 
Gumiński W.

1999 Kultura Zedmar a kultura Narva. Razem czy osobno. Światowit, 1(42), fasc. B, s. 59-69.

Jankowska D.

1983 Kultura pucharów lejkowatych i amfor kulistych na Pomorzu. W: T. Malinowski (red.), Problemy epoki kamienia na Pomorzu (s. 147-166). Słupsk: Wyższa Szkoła Pedagogiczna w Słupsku, Muzeum Pomorza Środkowego w Słupsku.

Jankowska D.

1990 Społeczności strefy poludniowo-zachodniobaltyckiej $w$ dobie neolityzacji. Poznań: Wydawnictwo Naukowe UAM.

Jankowska D.

1996 Neolit Pomorza Zachodniego - nierozwiązany problem badawczy. W: E. Wilgocki,

P. Krajewski, M. Dworczyk, D. Kozłowska (red.), 50 lat archeologii polskiej na Pomorzu Zachodnim (s. 11-25). Szczecin: Stowarzyszenie Naukowe Archeologów Polskich.

Jankowska D.

2001 Elementy leśne w neolicie Pomorza. Od neolityzacji do początków epoki brązu. W:

J. Czebreszuk, M. Kryvalcevic, P. Makarewicz (red.), Przemiany kulturowe w międzyrzeczu Odry i Dniepru między VI i II tys. przed Chr. (2, s. 85-99), Poznań: Wydawnictwo Poznańskie.

Jankowska D.

2009 Rozwój badań nad epoką kamienia na Pomorzu w ostatnim 25-leciu. W: M. Fudziński, H. Paner (red.), Aktualne problemy epoki kamienia na Pomorzu (s. 23-37). Gdańsk: Muzeum Archeologiczne w Gdańsku.

Kabaciński J., Sobkowiak-Tabaka I.

2004 Komorniki. Chata ludności kultury pucharów lejkowatych. Poznań: Poznańskie Towarzystwo Prehistoryczne, Instytut Archeologii i Etnologii Polskiej Akademii Nauk Oddział w Poznaniu.

Kirsch E.

1994 Beiträge zur älteren Trichterbecherkultur in Brandenburg. Potsdam: Verlag Brandenburgisches Landesmuseum für Ur- und Frühgeschichte.

Kobusiewicz M., Kabaciński J.

1993 Chwalim. Subboreal hunter-gatherers of the Polish plain. Poznań: Institute of Archaeology and Ethnology, Polish Academy of Sciences.

Kośko A.

1982 Z badań nad problematyką równoleżnikowych kontaktów kulturalnych społeczeństw dorzeczy Odry i Wisły w młodszej epoce kamienia (zagadnienie tzw. wpływów kultury michelsberskiej). Wiadomości Archeologiczne, 47, s. 161-169.

Kroitsch K.

1973 Die Gaterslebener Gruppe und ihre Stellung im Neolithikum des Elbe-Saale-Raums. (Neolitische Studien II). Halle: Martin-Luther-Universität Halle-Wittenberg.

Łuczak M.

2006 Szczecin-Gumieńce Scheune. Szczecin: Pomorskie Towarzystwo Historyczne.

Małecka-Kukawka J.

2001 Między forma a funkcją. Traseologia neolitycznych zabytków krzemiennych z ziemi chetmińskiej. Toruń: Wydawnictwo Naukowe Uniwersytetu Mikołaja Kopernika.

Mende J.

2001 Siedlungsreste der Trichterbecherkultur unter einem zerstörten Hügelgrab bei Warlin, Lkr. Mecklenburg-Strelitz. Archäologische Berichte aus Mecklenburg-Vorpommern, 8, s. 21-40. 
Menke M.

1988 Zu den frühen Kupferfunden des Nordens. Acta Archeologica, 59, s. 15-67.

Mierzwiński A.

2003 Znaki utrwalone w glinie. Wrocław: Instytut Archeologii i Etnologii Polskiej Akademii Nauk.

Osipowicz G.

2010 Narzędzia krzemienne w epoce kamienia na ziemi chetmińskiej. Studium traseologiczne,

Toruń: Wydawnictwo Naukowe Uniwersytetu Mikołaja Kopernika.

Osypiński P., Pyżewicz K.

2015 Znalezisko serii wiórów ze stanowiska 9 w Dąbrówce, gm. Kowal. Folia Praehistorica Posnaniensia, 20, s. 357-372.

Preuß J.

1966 Baalberge Gruppe in Mitteldeutschland (Veröffentlichungen des Landesmuseums für Vorgeschichte in Halle, 21). Berlin: Landesmuseums für Vorgeschichte in Halle.

Pyżewicz K.

2015 Analiza traseologiczna artefaktów krzemiennych. W: A. Marciniak, I. Sobkowiak-Tabaka, M. Bartkowiak i M. Lisowski (red.), Kopydlowo, stanowisko 6. Osady neolityczne z pogranicza Kujaw i Wielkopolski (s. 193-205). Poznań - Pękowice: Wydawnictwo i Pracownia Archeologiczna PROFIL-ARCHEO.

Pyżewicz K., Rozbiegalski P.

2012 Sposoby rozpalania ognia w młodszej epoce kamienia na terenie ziem polskich w kontekście badań eksperymentalno-traseologicznych, Światowit, Fascykut B, Archeologia pradziejowa i średniowieczna. Archeologia Polski, 9(50), s. 259-272.

Richthofen von B.

1934 Die Irdenware des nordeurasischen Kulturkreises der jüngeren Steinzeit in Schlesien. Altschlesien, 5, s. 67-83.

Rzepecki S.

2004 Społeczności środkowoneolitycznej kultury pucharów lejkowatych na Kujawach. Poznań: Wydawnictwo Poznańskie.

Sajkowska M.

1984 Grób skrzynkowy na stanowisku nr 7 w Mierzynie, gm. Dobra, woj. Szczecin. Materiaty Zachodniopomorskie, 29, s. 287-291.

Siuchniński K.

1958 Dotychczasowe wyniki badań na osadzie kultury pucharów lejkowatych w Ustowie, pow. Szczecin. Materiały Zachodniopomorskie, 4, s. 17-41.

Siuchniński K.

1961 Odkrycia. Materiaty Zachodniopomorskie, 7, s. 782.

Siuchniński K.

1969 Klasyfikacja czasowo-przestrzenna kultur neolitycznych na Pomorzu Zachodnim, cz. 1, Siuchniński K.

Katalog źródet archeologicznych. Szczecin: Muzeum Pomorza Zachodniego.

1972 Klasyfikacja czasowo-przestrzenna kultur neolitycznych na Pomorzu Zachodnim, cz. 2, Opracowanie analityczne. Szczecin: Muzeum Pomorza Zachodniego.

Siuchniński K.

1981 Zagadnienie grupy ustowskiej (britzko-ustowskiej) kultury pucharów lejkowatych. W: T. Wiślański (red.), Kultura pucharów lejkowatych (studia i materiały) (s. 137-161). Poznań: Polska Akademia Nauk, Oddział w Poznaniu i Leszczyńskie Towarzystwo Kulturalne w Lesznie. 
Siuchniński K.

1983 Stosunki kulturowe u ujścia Odry w neolicie i w początkach epoki brązu. W: W. Filipowiak, G. Labuda (red.), Dzieje Szczecina, t. 1, Pradzieje Szczecina (s. 103-278). Warszawa - Poznań: Państwowe Wydawnictwo Naukowe.

Szmyt M.

1996 Społeczności kultury amfor kulistych na Kujawach. Poznań: Uniwersytet im. Adama Mickiewicza w Poznaniu.

Szmyt M.

2003 On the Studies of the South-Western Peripheries of the Globular Amphora Culture. Przeglad Archeologiczny, 51, s. 87-123.

Terberger T., Seiler M.

2005 Flintschläger und Fischer- Neue interdisziplinäre Forschungen zu steinzeitlichen Siedlungsplätzen auf Rügen und dem angrenzenden Festland. Bodendenkmalpflege in Mecklenburg-Vorpommern, 52, s. 155-183.

Wiślański T.

1979 Kształtowanie się miejscowych kultur rolniczo-hodowlanych. Plemiona kultury pucharów lejkowatych. W: W. Hensel (red.), Prahistoria Ziem Polskich, t. 2, Neolit (s. 165-260). Wrocław - Warszawa - Kraków - Gdańsk: Ossolineum.

Wierzbicki J.

1999 Eupawski mikroregion osadniczy ludności kultury pucharów lejkowatych. Poznań: Wydawnictwo Naukowe UAM.

Winiarska-Kabacińska M.

2004 Analiza funkcjonalna zabytków krzemiennych. W: J. Kabaciński, I. Sobkowiak-Tabaka, Komorniki. Chata ludności kultury pucharów lejkowatych (s. 76-87). Poznań: Poznańskie Towarzystwo Prehistoryczne, Instytut Archeologii i Etnologii Polskiej Akademii Nauk Oddział w Poznaniu.

Wotzka P.H.

1998 Zur Michelsberge Höhenanlage mit Grabenwerk in Ranstadt-Dauernheim, Wetteraukreis. W: J. Biel, H. Schlichterle, M., Strobel A. Zeeb (red.), Die Michelsbecher Kultur und ihre Randgebiete- Probleme der Entstehung, Chronologie und des Siedlungswesens (Materialhefte zur Archäologie in Baden-Württemberg, 43, s. 85-96). Stuttgart: Konrad Theiss Verlag.

\section{THE RESULTS OF INVESTIGATIONS AT THE FUNNEL BEAKER CULTURE SETTLEMENT SITE IN MIERZYN, DOBRA SZCZECIŃSKA COMMUNE, SITE 4, AND THEIR SIGNIFICANCE FOR THE KNOWLEDGE OF THE MIDDLE NEOLITHIC IN THE LOWER ODER REGION}

\section{Summary}

Site 4 in Mierzyn, Dobra Szczecińska Commune, was discovered in 1929 by H. Bollnow. The first assemblage included a pointy-based vessel, which for over 70 years was attributed to the forest cultures, the Pit-Comb Ware culture, the ceramic Mesolithic or the proto-Neolithic.

At the beginning of the twenty-first century, the infrastructure for a planned housing estate was being developed in the area of the site, disturbing cultural layers, pits and the zones of activity 
of Neolithic communities (flint concentrations, clusters of burnt stones, pottery clusters). Once the excavated relics of the settlement site and flint workshops were uncovered, a question arose about their relative chronology and the relationship between the pits and flint concentrations registered on the surface and the excavated occupation horizons. A 2004 test pit survey of a TRB dwelling pit conducted as a result of collaboration between Adam Mickiewicz University and the National Museum in Szczecin, under the direction of T. Galiński, produced an assemblage of Neolithic pottery and the evidence of flint production. The pit yielded a fragment of a vessel with a pointed base that prompted the reinterpretation of the 1929 find.

The pottery and flint artefacts have been subject to comprehensive analyses. Despite its poor state of preservation, the pottery could be described in terms of style and technology. We analysed the recipes, techniques used for building vessel walls and shaping preferred forms. The description of flint artefacts is enriched with documentation of a microscopic analysis conducted by K. Pyżewicz of UAM, who participated in the investigations. A use-wear analysis allowed us to identify flint artefacts showing use-wear, which suggests their domestic use.

The pointy-based vessels from Mierzyn seem to be related to the influence of the Michelsberg culture; they should be discussed in the context of the so-called Pasewalk beakers. The technological and stylistic data allow us to narrow the chronology of the feature to the period between 3700 and $3400 \mathrm{BC}$. 